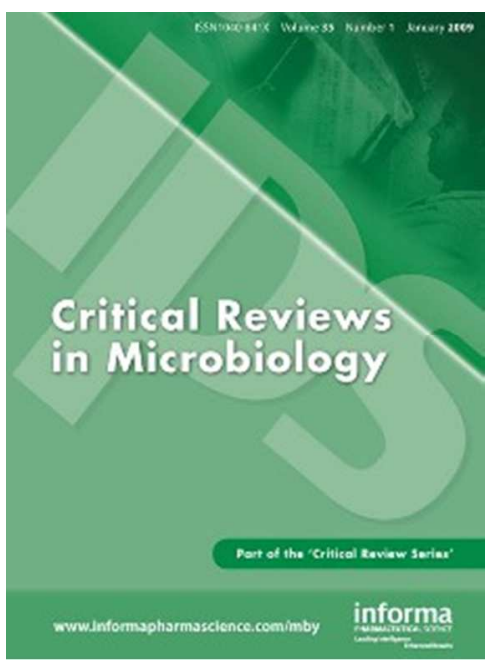

\title{
Bacterial pathogens activate plasminogen to breach tissue barriers and escape from innate immunity
}

\begin{tabular}{|r|l|}
\hline Journal: & Critical Reviews in Microbiology \\
\hline Manuscript ID: & BMCB-2015-0004.R1 \\
\hline Manuscript Type: & Reviews \\
\hline Keywords: & Bacteria, Plasminogen, Invasion, Innate immunity, Fibrinolysis \\
\hline \multicolumn{2}{|l}{} \\
\hline
\end{tabular}

\section{SCHOLARONE ${ }^{m}$}

Manuscripts 
Bacterial pathogens activate plasminogen to breach tissue barriers and escape from innate immunity

Word count: 4492 (abstract 127, article 4365)

\author{
Key terms \\ Fibrinolysis \\ Plasminogen \\ Plasmin \\ Proteolysis \\ Staphylokinase \\ Streptokinase
}




\begin{abstract}
Both coagulation and fibrinolysis are tightly connected with the innate immune system. Infection and inflammation cause profound alterations in the otherwise well-controlled balance between coagulation and fibrinolysis. Many pathogenic bacteria directly exploit the host's hemostatic system to increase their virulence. Here, we review the capacity of bacteria to activate plasminogen. The resulting proteolytic activity allows them to breach tissue barriers and evade innate immune defense, thus promoting bacterial spreading.

Y. pestis, streptococci of group A, C and G and S. aureus produce a specific bacterial plasminogen activator. Moreover, surface plasminogen receptors play an established role in pneumococcal, borrelial and group B streptococcal infections.
\end{abstract}

This review summarizes the mechanisms of bacterial activation of host plasminogen and the role of the fibrinolytic system in infections caused by these pathogens. 
Introduction

The coagulation system and the innate immune defense share the same evolutionary origin. Tissue damage, as well as bacterial infection and local inflammation trigger activation of the coagulation system, which results in thrombin generation and fibrin deposition. Fibrin not only seals off leaking blood vessels, but also constitutes a first barrier against bacterial spread. Moreover, it provides a scaffold for inflammatory cells that aim at remodeling and restoring normal tissue architecture. The coagulation cascade is balanced by an anticoagulant system that avoids excessive coagulation and a fibrinolytic system that is able to dissolve fibrin clots. Excessive activation of both the coagulation and the fibrinolytic system contributes to the mortality of severe infections and inflammatory diseases (Verhamme \& Hoylaerts, 2009).

Plasmin, the central enzyme of the fibrinolytic system, is a serine protease that is derived from its inactive zymogen precursor, plasminogen (Plg). Although fibrin is considered to be the main physiological substrate of plasmin, the proteolytic spectrum of plasmin also includes extracellular matrix (ECM) proteins. Besides fibrinolysis, Plg is implicated in many physiological processes such as cell migration, wound healing, angiogenesis and embryogenesis. Malignant cells can usurp the fibrinolytic system to invade tissues and disseminate to other body sites (Law et al., 2013).

Bacterial pathogens have developed various ways to interact with Plg and use the host's powerful proteolytic system to their own advantage. Abusing these otherwise tightly controlled cascades allows them to escape primary defense systems and to promote their 
dissemination through tissue barriers. While a few bacteria produce specific Plg activators, of which streptokinase, staphylokinase, and the Pla protease from $Y$. pestis are the most renowned, a vast group of pathogens can capture the host's PIg to their surface. In this review, we discuss the role of coagulation and fibrinolysis in inflammation, and focus on Plg activation as a virulence strategy in bacterial infections. 
The fibrinolytic system: a tightly controlled, broad-spectrum proteolytic system

\begin{abstract}
The central component of the fibrinolytic system is plasminogen (Plg), the zymogen form of plasmin. Plasmin cleaves insoluble fibrin polymers into soluble fragments (Law et al., 2013, Rijken \& Lijnen, 2009). Similar to other protease-dependent cascade systems, such as the coagulation and the complement system, its activity is regulated by different activators and inhibitors (Figure 1).
\end{abstract}

\title{
Plasminogen (Figure 2)
}

Plasminogen is a $90 \mathrm{kDa}$ proenzyme that is abundantly present in plasma with concentrations ranging from 180 to $200 \mu \mathrm{g} / \mathrm{ml}$ or about $2 \mu \mathrm{M}$. Conversion to active plasmin, by cleavage of the peptide bond $\mathrm{Arg}^{561}-\mathrm{Val}^{562}$ by specific Plg activators leads to the formation of a heavy chain and a light chain that remain joined through two disulfide bridges (Rijken \& Lijnen, 2009) (Figure 2). While the light chain contains the catalytic triad $\mathrm{His}^{603}, \mathrm{Asp}^{643}$ and $\mathrm{Ser}^{741}$, which forms the serine protease active site, the heavy chain consists of five kringle domains with lysine-binding sites that allow interaction with target molecules and Plg receptors (PlgRs) (Castellino \& Ploplis, 2005, Law et al., 2013). Binding to PlgRs facilitates conversion to plasmin and receptor-bound plasmin is protected from inactivation by the physiological inhibitor $\alpha_{2}$-antiplasmin. The plasmin-mediated removal of an N-terminal $8 \mathrm{kDa}$ activation peptide turns native Plg (Glu-Plg) into Lys-Plg, with a more open conformation allowing stronger interaction with target molecules and also facilitating conversion to plasmin (Castellino \& Ploplis, 2005, Law et al., 2013). 


\section{Plasminogen activators}

Mammals have two distinct Plg activators, tissue-type plasminogen activator (t-PA) and urokinase (u-PA) (Rijken \& Lijnen, 2009). The $70 \mathrm{kDa}$ t-PA is produced mainly by endothelial cells and activates PIg in the presence of fibrin (Lijnen \& Collen, 1988), leading to lysis of intravascular fibrin clots. u-PA (54 kDa) binds to cellular u-PA receptors (u-PAR) and activates Plg at the cell surface (Blasi et al., 1986, Vassalli et al., 1985). This cell-surface associated plasmin activity is involved in cell adhesion and cell migration through ECM (Chapman, 1997, Law et al., 2013, Miles \& Parmer, 2013, Rijken \& Lijnen, 2009).

Although these Plg activators regulate very distinct processes, t-PA- or u-PA-deficient mice have only minor changes in their fibrinolytic capacity. Only with combined t-PA- and u-PAdeficiency extensive spontaneous fibrin deposition will develop, suggesting that the roles of t-PA and u-PA are in part redundant (Bugge et al., 1996a, Carmeliet et al., 1994).

\section{Plasmin substrates and physiological functions of plasmin}

Plasmin is a serine protease that cleaves peptide bonds C-terminal of a lysine or arginine residue. Plasmin has a broad spectrum of substrates. Fibrin is considered as the main physiological substrate of plasmin, but plasmin also degrades ECM proteins such as laminin, fibronectin, vitronectin and heparan sulfate proteoglycans. Although collagen is not susceptible to plasmin digestion, plasmin can activate procollagenases, indirectly leading to collagen degradation (Makowski \& Ramsby, 1998, Monea et al., 2002, Murphy et al., 1992). The ECM degradation resulting from this crosstalk between proteolytic enzyme systems is involved in the migration of leukocytes to the site of inflammation (Del Rosso et al., 2008). 


\section{$\underline{\text { Plasmin inhibition }}$}

To avoid widespread proteolytic tissue degradation by plasmin, its activity is controlled not only at the level of Plg activation, but also by direct inactivation of plasmin. In addition, PlgRs confine the activity of plasmin to the cell surface, thus protecting against diffuse proteolytic damage (Miles \& Parmer, 2013, Rijken \& Lijnen, 2009).

Although the aspecific protease inhibitor $\alpha_{2}$-macroglobulin, abundantly present in plasma, inactivates plasmin, the main physiological plasmin inhibitor is the serine protease inhibitor (serpin) $\alpha_{2}$-antiplasmin (Rijken \& Lijnen, 2009). $\alpha_{2}$-antiplasmin inactivates plasmin by covalently binding the serine residue of the catalytic site. This process is facilitated by the interaction between the kringle domains 1-3 of plasmin and the carboxy-terminal domain of $\alpha_{2}$-antiplasmin. Fibrin and PlgRs both use the lysine-binding sites to bind plasmin(ogen), which explains why fibrin and cell-surface bound plasmin is less susceptible to $\alpha_{2^{-}}$ antiplasmin inactivation (Rijken \& Lijnen, 2009).

The plasminogen activator inhibitors (PAIs) also belong to the serpin family. PAI-1 inhibits tPA and $\mathrm{u}-\mathrm{PA}$, and is implicated in cell migration, tumor development and cardiovascular diseases (Declerck \& Gils, 2013, Lijnen, 2005). The exact role of the mainly intracellularly located PAI-2 as inhibitor of fibrinolysis is more controversial (Gardiner \& Medcalf, 2014). 
Thrombin-activatable fibrinolysis inhibitor (TAFI) is a carboxypeptidase. The removal of Cterminal lysine residues of fibrin and PIgRs by TAFI impairs Plg binding. TAFI is activated by the thrombin-thrombomodulin complex and links coagulation, inflammation and fibrinolysis (Colucci \& Semeraro, 2012, Rijken \& Lijnen, 2009). 
The role of fibrin and fibrinolysis in host defense

\begin{abstract}
Coagulation as well as fibrinolysis are closely intertwined with the innate immunity. A better understanding of the complex interactions between the hemostatic and the immune system is crucial to comprehend the manipulation of these pathways by bacteria.
\end{abstract}

\title{
Fibrin and host defense: coagulation as part of the innate immunity
}

The extensive crosstalk between coagulation and inflammation is reviewed in detail elsewhere and is beyond the scope of this article (Levi \& Van Der Poll, 2010). Both systems, directed to protect the host from physical or biological injury, share a common evolutionary origin. An example is the clotting of hemolymph in the horseshoe crab as a response to either exoskeleton damage or bacterial infection (Delvaeye \& Conway, 2009).

It has long been known that fibrin deposition is essential for abscess formation, allowing the host to encapsulate and prevent further spread of bacterial infections (Luo et al., 2013). Fibrinogen depletion leads to impaired abscess formation in mice after intraperitoneal inoculation, and causes more widespread disease (McRitchie et al., 1991). Mice with reduced fibrinogen levels or reduced thrombin activity are markedly more sensitive to infection by group A streptococci and Y. enterocolitica (Luo et al., 2011, Sun et al., 2009).

Fibrin also provides a scaffold for inflammatory reactions. Binding of the leukocyte integrin receptor $\alpha_{M} \beta_{2}$ to the fibrin(ogen) gamma chain residues 390-396 is crucial for the efficient recruitment and activation of neutrophils and macrophages. Mutation of this $\alpha_{M} \beta_{2}$ binding region does not affect coagulation, but strongly reduces the clearance of $S$. aureus (Flick et 
al., 2004a, Flick et al., 2004b) and increases mortality of group A streptococcal infection (Sun et al., 2009). Also, in a pneumonic plague model, successful phagocytic and T cell mediated defense was dependent on the presence of a fibrin matrix surrounding $Y$. pestis bacteria (Luo et al., 2013).

\section{Fibrinolysis and host defense}

The interaction between inflammation and coagulation also extends to the fibrinolytic system. Plasmin is involved in many inflammatory reactions such as complement activation, the bradykinin system and migration of leukocytes (Bugge et al., 1996b, Del Rosso et al., 2008). Plg deficient mice show impaired leukocyte migration and have defective wound healing and tissue repair mechanisms (Schuster et al., 2007).

PAI-1 is upregulated in local as well as systemic inflammatory processes (Chung et al., 2009, Lim et al., 2011, Mandl-Weber et al., 2001, Renckens et al., 2007) and PAI-1 levels correlate with mortality in severe sepsis, both in mouse models (Lim et al., 2011, Raeven et al., 2012, Renckens et al., 2007) and in patients (Green et al., 2002, Lorente et al., 2014, Madoiwa et al., 2006, Pralong et al., 1989, Raaphorst et al., 2001, Skibsted et al., 2013). A polymorphism in the PAI-1 gene affects the likelihood of patients with meningococcal infection to develop sepsis or DIC (Binder et al., 2007, Westendorp et al., 1999); for pneumococcal meningitis an association of the polymorphism with increased mortality and cerebrovascular complications was found (Brouwer et al., 2014). The same PAI-1 polymorphism predicts mortality in sepsis patients (Li et al., 2013). The reduction of PAl-1 activation by means of a 
monoclonal antibody against PAI-1 reduced kidney injury and mortality in a model of disseminated intravascular coagulation (Montes et al., 2000).

Although the role of TAFI in infection is less clear, inhibition or absence of TAFI also reduced organ dysfunction in sepsis caused by $P$. aeruginosa or $E$. coli and in endotoxin shock models (Colucci \& Semeraro, 2012, Muto et al., 2009, Renckens et al., 2011).

However, despite the strong correlation between elevated antifibrinolytic activity and mortality, elevated PAI-1 levels have been shown to be protective in murine models of $K$. pneumoniae and $H$. influenzae pneumonia as well as in melioidosis by sustaining neutrophil influx towards the infectious focus, thus minimizing bacterial spreading and pathogeninduced damage (Kager et al., 2011, Lim et al., 2011, Renckens et al., 2007, Wang et al., 2013).

This indicates that despite the risks of an unbalanced coagulation, the inhibition of fibrinolysis can also be favorable to combat certain microorganisms. In this respect, it has been shown that Plg deficiency improves outcome in S. aureus sepsis, however, only if very high inocula are used (Guo et al., 2011). Increased Plg activation by administration of t-PA or by absence of its inhibitors increases mortality in B. pseudomallei and $Y$. enterocolitica sepsis (Kager et al., 2012, Kager et al., 2013, Luo et al., 2011). 


\section{Bacteria and the plasminogen activator system}

The Plg system constitutes a potent proteolytic potential that pathogens can usurp to promote their own spreading through tissue barriers. For an increasing number of bacteria, the ability to interact with the Plg system has been strongly linked to their pathogenic potential.

Next to their Plg activating potential, many bacterial pathogens also directly activate the coagulation cascade resulting in fibrin deposition. Bacterial substances such as lipopolysaccharide and lipoteichoic acid stimulate coagulation via tissue factor secretion, and inhibit anticoagulation and fibrinolysis (Hoogerwerf et al., 2009, Schlichting et al., 1993). Bacteria can induce contact pathway activation as well (nicely reviewed in Nickel \& Renné, 2012). Bacterial surface molecules such as the M protein of S. pyogenes and curli from E. coli can bind high molecular weight kininogen to the bacterial surface. Furthermore, bacteria can release polyphosphate and thus activate factor XII. Some bacterial proteases such as staphopains from S. aureus and SpeB from S. pyogenes can directly cleave high molecular weight kininogen to release bradykinin.

The most striking example of bacterial specialization to subvert physiological hemostasis is observed in S. aureus. The coagulase activity of $S$. aureus is caused by the production of two bacterial prothrombin activators, staphylocoagulase and von Willebrand factor binding protein. Both proteins conformationally activate prothrombin to yield active staphylothrombin, which is able to generate fibrin and provide $S$. aureus bacteria with shelter from the host defense system (Vanassche et al., 2011). In gram-negative bacteria, 


\section{Bacterial plasminogen receptors}

The capacity to engage the host plasmin system at the bacterial surface seems to be almost universal.

Interestingly, bacterial PlgRs can be specialized cell surface proteins, but also multifunctional glycolytic enzymes with a partial surface localization (Chhatwal, 2002, Pancholi \& Chhatwal, 2003). Binding of the lysine-binding sites in the Plg kringle domains facilitates the activation of Plg to surface-bound plasmin, and protects the resulting plasmin from inactivation (Bhattacharya et al., 2012, Hall et al., 1991, Lahteenmaki et al., 2001, Sanderson-Smith et al., 2012).

In gram-positive bacteria, the most important PlgRs are the glyceraldehyde-3 phosphate dehydrogenase (GAPDH), also known as Plr or SDH in group $A, B$ and $C$ streptococci (Bergmann et al., 2004, Boël et al., 2005, Kinnby et al., 2008, Lama et al., 2009, Matta et al., 
2010, Pancholi \& Fischetti, 1992, Seifert et al., 2003, Winram \& Lottenberg, 1996). In addition, $\alpha$-enolase is implicated in surface Plg binding in staphylococci, streptococci, trichomonas, mycoplasma and B. anthracis (Agarwal et al., 2008, Bergmann et al., 2001, Chumchua, et al., 2008, Ehinger et al., 2004, Esgleas et al., 2008, Jones \& Holt, 2007, Kinnby et al., 2008, Molkanen et al., 2002, Mundodi et al., 2008, Pancholi \& Fischetti, 1998, Whiting et al., 2002, Yavlovich et al., 2007,), and is also present on the surface of eukaryotic cells (Miles et al., 1991). Furthermore, streptococci can bind Plg through PAM (streptococcal M protein) (Berge \& Sjobring, 1993, Fu et al., 2008).

The capacity to bind Plg and acquire pericellular proteolytic activity has also been demonstrated in many gram-negative bacteria (Ullberg et al., 1990). Adhesion structures such as fimbriae and flagella are often involved in this interaction (Lahteenmaki et al., 1993, Sjobring et al., 1994). Fimbriae from pathogenic E. Coli act as PlgRs (Kukkonen et al., 1998, Parkkinen \& Korhonen, 1989). They also bind t-PA (Sjobring et al., 1994) and mediate adhesion to ECM components, thus colocalizing the proteolytic machinery to the ECM. The presence of $\alpha$-enolase and GAPDH has also been shown in gram-negative organisms and spirochetes (Egea et al., 2007, Floden et al., 2011, Knaust et al., 2007, Sha et al., 2009, Sijbrandi et al., 2005,). The spirochetes Borrelia and Leptospira furthermore possess an extensive arsenal of specialized surface PlgRs (Brissette et al., 2009, Fuchs et al., 1994, Hallstrom et al., 2010, Hu et al., 1997, Rossmann et al., 2007, Vieira et al., 2012).

The expression of bacterial Plg activators and PlgRs are not mutually exclusive strategies, but rather seem to complement each other. Oral streptococci express both streptokinase and PlgRs (Kinnby et al., 2008). In a model of impetigo, both streptokinase and the PlgR 


\section{Bacterial plasminogen activators}

\section{Streptokinase}

Streptokinase is produced by group A, C and $G \beta$-hemolytic streptococci. It consists of a single polypeptide chain with a $\alpha, \beta$ and $\gamma$ domain. Polymorphisms allow for distinction between clusters 1 and 2 (2a/2b) of streptokinase alleles (Cook et al., 2012, Zhang et al., 2012b). Streptokinase expression is upregulated by the FasBCAX system, a homologue of the agr quorum sensing system in staphylococci (Sun et al., 2012). Interaction of the streptokinase $\alpha$ and $\gamma$ domain with Plg induces a conformational change that exposes the catalytic site, leading to Plg activation without hydrolysis of the $\mathrm{Arg}^{561}-\mathrm{Val}^{562}$ bond (Wang et al., 1998). This streptokinase-plasmin(ogen) complex can consequentially activate other Plg molecules into plasmin. Furthermore, this conformational change protects the streptokinase-plasmin(ogen) complex from inactivation by $\alpha_{2}$-antiplasmin (CederholmWilliams et al., 1979). However, Plg-activating properties differ between streptokinase gene clusters. Streptokinase cluster type $2 \mathrm{~b}$ has a weaker Plg-activating effect and is inhibited by $\alpha_{2}$-antiplasmin; this streptokinase variant was less virulent in a mouse model (Cook et al., 2012). In S. pyogenes strains with this streptokinase type $2 b$, there is a strong coinheritance with the major streptococcal surface PIgR, PAM (Zhang et al., 2012b). 
In contrast to u-PA and t-PA, streptokinase has a strong species-specificity, as human pathogenic streptococci do not activate murine Plg and vice versa (Sun et al., 2004). Streptokinases of non-human streptococci show remarkable species-specificity for the Plg of the animals they infect (Caballero et al., 1999, Leigh et al., 1998, McCoy et al., 1991). S. uberis, a major cause of bovine mastitis, even secretes an unrelated streptococcal Plg activator known as PauA or SUPA, which is specific for bovine and ovine Plg (Rosey et al., 1999, Ward et al., 2004, Zhang et al., 2012a).

Mice are naturally resistant to streptococcal skin infection. This can be explained by the species-specificity of streptokinase for human (and not murine) Plg, as expression or addition of human Plg in a mouse model strongly increased the pathogenic potential (Khil et al., 2003, Li et al., 1999, Ly et al., 2014, Sun et al., 2004).

However, both Plg activation by streptokinase and PIg binding by PAM are species-specific and play an important role in group A streptococcal pathogenesis (Fu et al., 2008, Sanderson-Smith et al., 2008, Sun et al., 2012, Svensson et al., 2002). Invasive isolates of group A streptococci efficiently assemble a trimolecular complex of fibrinogen-Plgstreptokinase through interaction with PAM and M-related proteins (McKay et al., 2004).

\section{Staphylokinase}

The smaller staphylokinase protein, secreted by the majority of pathogenic $S$. aureus isolates, is structurally unrelated to streptokinase. Its sequence is highly conserved and it is carried on a beta-hemolysin-converting bacteriophage (Coleman et al., 1989, Sumby \& Waldor, 2003, Van Wamel et al., 2006). Staphylokinase expression is controlled by quorum- 
sensing signals via the agr gene regulator (Novick, 2003). The large majority of human clinical isolates are staphylokinase positive and most reports find similar or higher prevalence of staphylokinase-producing strains in clinical infections compared to colonization, especially for skin and soft tissue or bone infections (Humphreys et al., 1989, Luedicke et al., 2010, Monecke et al., 2007, Monecke et al., 2009, Piechowicz et al., 2010, Ruotsalainen et al., 2008, Van Wamel et al., 2006, Wieckowska-Szakiel et al., 2007). Staphylokinase production constitutes an adaptation to the human host, as the gene encoding staphylokinase is lost after transition to animals (Katayama et al., 2013, Resch et al., 2013).

Although staphylokinase, like streptokinase, is not a protease, there are some important mechanistic differences. Staphylokinase has only a weak affinity for Plg, and the staphylokinase-Plg complex is enzymatically inactive. In contrast, staphylokinase had a high affinity for binding to traces of plasmin that are present in plasma (Collen et al., 1993, Silence et al., 1993) and the resulting staphylokinase-plasmin complex is enzymatically active and converts Plg into plasmin. The staphylokinase-plasmin complex is readily inactivated by $\alpha_{2}$-antiplasmin, but binding to fibrin or PlgRs via its lysine-binding sites, protects staphylokinase-plasmin from inactivation (Lijnen et al., 1991). This has major implications, as it makes staphylokinase a fibrin-specific Plg activator.

Due to this ability to provide fibrin-specific proteolytic activity without systemic Plg activation, staphylokinase has been evaluated as a fibrin-specific thrombolytic agent, in contrast to the non-fibrin-specific streptokinase (Collen, 1998). The protection of the staphylokinase-plasmin complex from inhibition by $\alpha_{2}$-antiplasmin by surface PIgRs or by fibrin - similar to streptokinase type $2 b$ (Cook et al., 2014) - can confine the associated proteolytic activity to specific niches, close to the bacterial colony or the surrounding fibrin. 
Interestingly, the coagulase-positive $S$. aureus is also able to generate its own fibrin scaffold by staphylocoagulase activity.

Although staphylokinase is well-studied in cardiovascular science, its role in staphylococcal virulence remained unresolved.

High-level staphylokinase production significantly reduces sepsis mortality, decreases spread of skin infection and is incompatible with successful biofilm infection (Kwiecinski et al., 2010, Kwiecinski et al., 2013, Kwiecinski et al., 2014). Most likely, these observations can be explained by interference of hyperfibrinolysis with bacterial-induced fibrin formation, which was shown to be an important virulence factor of $S$. aureus in bacteremia, abscess formation and catheter infection (Cheng et al., 2010, McAdow et al., 2011, Vanassche et al., 2011, Vanassche et al., 2013). However, in a mouse model with human Plg expression through adenoviral gene transfer, staphylokinase-mediated Plg activation in case of normal-level staphylokinase production, was shown to increase lesion size and bacterial load (Peetermans et al., 2014).

\section{Pla}

The $Y$. pestis outer membrane protein Pla is a protease that, although structurally unrelated to mammalian Plg activators, activates Plg by proteolysis of the same $\mathrm{Arg}^{561}-\mathrm{Val}^{562}$ peptide bond. Pla also activates pro-u-PA (Jarvinen et al., 2013). Furthermore, Pla inactivates the fibrinolytic inhibitors $\alpha_{2}$-antiplasmin, PAI-1 and TAFI (Haiko et al., 2010, Kukkonen et al., 2001, Valls Seron et al., 2010). Pla is part of a family of outer membrane proteins (omptins) present in gram-negative bacteria. Homologues in other species include OmpT from E. coli 
The role of Plg activation as a virulence factor has perhaps been most extensively documented in Y. pestis (Korhonen et al., 2013). The virulence of a Pla-negative mutant was decreased by a factor 1000000 after subcutaneous administration (Sodeinde et al., 1992), while Pla-negative mutants retained virulence when injected intravenously (Sebbane et al., 2006, Sodeinde et al., 1992). This strongly suggests the importance of Pla for the dissemination through skin and soft tissue. While Pla-negative $Y$. pestis can cause systemic spread when inoculated intranasally, these mutants were less capable of inducing pulmonary infection (Lathem et al., 2007). Plg deficient mice had a strongly reduced mortality compared to wild-type mice (100-fold increase in $L_{50}$ ) (Goguen et al., 2000). Nevertheless, the protective effect of Plg gene deletion was not as profound as that of Pla inactivation, suggesting that at least some of the pathogenic potential of Pla is independent from its Plg-activating function. 


\section{Mechanisms of plasmin(ogen)-dependent bacterial virulence (Figure 3)}

Table 1 and 2 summarize the experimental evidence for the role of Plg activation in bacterial pathogenicity, derived from in vitro data (Table 1) and animal models (Table 2).

\section{Extracellular matrix degradation}

An increasing body of in vitro and in vivo evidence shows that bacteria rely on Plg activation to breach through cellular monolayers, degrade ECM and facilitate bacterial spreading.

The involvement of Plg in matrix and basement membrane degradation has been shown for H. influenzae and S. pneumoniae. In addition, N. meningitidis is also able to bind human PIg (Knaust et al., 2007, Ullberg et al., 1992). These three pathogens are the most important causes of bacterial meningitis. In vivo experiments have shown that Plg activation by Borrelia spp. facilitates penetration of the blood brain barrier (Gebbia et al., 1999, Nordstrand et al., 2001). The opportunistic pathogen C. neoformans, a yeast that typically causes meningitis in AIDS patients, also uses PIg to breach through matrix barriers (Stie et al., 2009). The capacity to engage plasmin activity may be crucial for the penetration of bacteria into the central nervous system, highlighting the clinical relevance of this pathogenhost interaction.

In a staphylococcal skin infection model, activation of Plg by staphylokinase and secondary MMP-activation led to increased subcutaneous spreading of infection (Peetermans et al., 2014). In group A streptococcal infection, necrotic skin lesions and increased mortality were observed if both streptokinase and human Plg were present (Khil et al., 2003, SandersonSmith et al., 2008). 
2. Escape from innate immunity

Host plasmin-mediated proteolysis can also be beneficial for bacteria by degrading peptides and proteins involved in first-line defense mechanisms. These include complement components and antimicrobial peptides such as defensins.

Surface-bound plasmin activity in Borrelia spp. has an anti-opsonic effect by decreasing C3b deposition (Koenigs et al., 2013). In F. tularensis, removal of bound IgG by surfaceassociated plasmin leads to decreased phagocytosis by macrophages (Crane et al., 2009). A similar protective effect was seen in group A streptococci and S. aureus (Koch et al., 2012, Ly et al., 2014, Rooijakkers et al., 2005, Siemens et al., 2011). Staphylokinase induces a rapid release of $\alpha$-defensins but also subsequently degrades and thus neutralizes their antimicrobial effect (Jin et al., 2004). Cathelicidin, another antimicrobial peptide, is upregulated in the airways after bacterial infection. Staphylokinase binds cathelicidin and this interaction enhances staphylokinase-mediated fibrinolysis (Braff et al., 2007).

\section{Fibrin degradation}

As noted above, activation of coagulation and the resulting encapsulation of bacteria with fibrin can be considered as part of the innate immune response to infection. Bacterialinduced plasmin activity can degrade this fibrin network to promote bacterial spreading.

Plg deficiency dramatically reduced mortality from $Y$. pestis in mice, but this survival benefit was lost in mice with a combined fibrinogen and Plg deficiency that failed to generate inflammatory infiltrates (Degen et al., 2007).

S. aureus biofilms on foreign surfaces contain large amounts of fibrin, generated by host thrombin as well as bacterial staphylothrombin activity. As the bacterial population 
increases, quorum-sensing mechanisms are activated, and staphylokinase production will increase. This will shift the balance from staphylocoagulase activity resulting in fibrin formation, to local degradation of fibrin mediated by the fibrin-specific plasminogen activator of S. aureus. Plg activation by staphylokinase dissolves staphylococcal biofilm matrix and thus allows detachment of bacteria to disseminate to new sites (Kwiecinski et al., 2014, Otto, 2004).

Interfering with bacterial plasminogen activation: therapeutic potential?

Despite promising data from studies in knock-out mice or with mutant bacteria (Table 1-2), few therapeutic applications have made the transition to patient care, with the exception of the use of streptokinase and staphylokinase as thrombolytic drugs in cardiovascular thrombosis (Collen, 1998). There are several explanations for this lack of translation to the clinical practice of infectious diseases.

First, many bacteria have redundant mechanisms to interact with Plg, e.g. combining several types of surface PlgRs with the secretion of a bacterial plasminogen activator. Also, some virulence factors have pleiotropic functions beyond their Plg activating potential. For example, streptococcal M protein does not only interact with Plg, but also with fibrinogen, kininogen, immunoglobulins, $\mathrm{C} 4 \mathrm{~b}$ binding protein, factor $\mathrm{H}$ and factor $\mathrm{H}$-like protein, thus accounting for its role as an antiphagocytic factor (Smeesters et al., 2010). M protein vaccines are currently under development, however their protective efficacy relies on the production of opsonizing antibodies rather than on the interference with Plg binding to $S$. pyogenes (Dale et al., 2013). The same holds true for borrelial vaccines directed to OspC 
(Scheiblhofer et al., 2003, Wagemakers et al., 2014) and pneumococcal vaccines based on $\alpha$-enolase (Adrian et al., 2004).

Secondly, some major virulence factors such as Pla from $Y$. pestis have failed as vaccine antigens. The protective efficacy of Pla-based immunization in animal models was dependent on the type of infection (bubonic vs. pneumonic plague) and the rodent model used (Erova et al., 2013, van Lier et al., 2014).

Thirdly, inhibition of fibrinolytic activity might increase fibrin encapsulation of bacteria, resulting in chronic and persistent infections. Remarkably, some bacteria interact with both coagulation and fibrinolysis. This apparent contradiction can be understood by the regulated expression of different virulence factors, depending on the growth phase of the bacteria. In some stages or types of infection, preventing coagulation cascade activation rather than inhibiting fibrinolysis, could be a more effective therapeutic strategy. Examples are interference with bacterial activation of the contact pathway (Oehmcke et al., 2009) or bacterial prothrombin activation (Peetermans et al., 2015). Importantly, catheter lock therapy with rt-PA was shown to prevent catheter related bacteremia in hemodialysis patients, probably by reducing fibrin deposition and bacterial adhesion (Hemmelgam et al., 2011). Some case reports and small trials describe the use of thrombolytic agents in the adjunctive treatment of fibrinopurulent infections of the pericardium, catheters or other foreign bodies (Bigham et al., 2008, Innes et al., 1994, Levitas et al., 2015, Masuya et al., 2006, Reznikoff et al., 2003, Wiggins et al., 2007). In fact, exogenously administered fibrinolytics are used here to break down the fibrin-encapsulated bacterial colony adhering to a foreign body; a strategy that is utilized on a smaller scale by $S$. aureus bacteria that produce staphylokinase to escape from an established biofilm when quorum sensing mechanisms are activated. 
However, in acute locally invasive or tissue destructive infections such as group A or B streptococcal infections, where proteolytic activation has been shown to be a major virulence factor, it is tempting to speculate for an adjunctive effect of plasmin inhibitors in their treatment. In a study by Khil and colleagues (Khil et al., 2003), coadministration of group A streptococci with human Plg led to necrotic skin lesions in mice. Those lesions were almost completely absent if an irreversible plasmin inhibitor was added to the inoculum. In a mouse model for group B streptococcal neonatal meningitis and sepsis, administration of epsilon-aminocaproic acid to the drinking water of the mothers was associated with less mortality, less tissue invasion of brain and lungs and lower organ bacterial load in neonates (Magalhaes et al., 2013). Clinical data on the potential use of plasmin inhibitors in rapidly spreading skin and soft tissue infections are not yet available.

A few recent publications have explored new pathways for therapeutic targeting of bacterial activation of host Plg. For examples, a promising strategy used a small molecule that interferes with bacterial gene regulation of S. pyogenes (possibly through inhibition of FasBCAX) and reduces streptokinase expression almost fourfold (Sun et al., 2012). Targeting the regulation of virulence factor expression is being investigated for $Y$. pestis and S. aureus infections as well (Gray et al., 2013, Murray et al., 2014, Zhan el al., 2008). 


\section{Conclusion}

While the coagulation system provides a first barrier against physical and biological damage, overwhelming coagulation activation increases mortality in severe inflammatory states. The fibrinolytic system protects against unwanted fibrin formation, but is also crucial for many other physiological and pathological processes that require cell migration. The balance between adequate coagulation and fibrinolysis is tightly connected to inflammation and the immune system.

The virulence of bacteria capable of causing human disease in part depends on the evolved ways to bypass innate immunity. The available evidence shows that in many cases tissue damage, bacterial spreading and even lethal potential does not result directly from bacterial enzymes, but from the host's own built-in proteolytic system that is subverted by the pathogen. Plasmin-mediated fibrinolysis helps to overcome the initial fibrin deposition that acts as first-line host response mechanism. Subsequent spreading through tissue barriers, as well as degradation of peptides of the innate immune system can be mediated by Plg activation, which is facilitated or induced by the pathogen's PlgRs and Plg activators. The understanding of these mechanisms may lead to the development of novel therapeutic strategies. 


\author{
Abbreviations \\ $\mathrm{ECM}=$ extracellular matrix \\ $\mathrm{Plg}=$ plasminogen \\ $\mathrm{PlgR}(\mathrm{s})=$ plasminogen receptor(s) \\ $\mathrm{t}-\mathrm{PA}=$ tissue-type plasminogen activator \\ $\mathrm{u}-\mathrm{PA}=$ urokinase \\ $\mathrm{u}-\mathrm{PAR}=\mathrm{u}-\mathrm{PA}$ receptor \\ PAI = plasminogen activator inhibitor \\ $\mathrm{TAFI}=$ thrombin-activatable fibrinolysis inhibitor \\ GAPDH = glyceraldehyde-3 phosphate dehydrogenase \\ PAM = streptococcal $M$ protein \\ $\mathrm{MMP}=$ matrix metalloproteinase
}




\section{References}

Adrian, PV, Bogaert, D, Oprins, M, Rapola, S, Lahdenkari, M, Kilpi, T, de Groot, R, Käyhty, H \& Hermans, PW. (2004) Development of antibodies against pneumococcal proteins alpha-enolase, immunoglobulin $A 1$ protease, streptococcal lipoprotein rotamase $A$, and putative proteinase maturation protein $A$ in relation to pneumococcal carriage and Otitis Media. Vaccine, 22, 2737-42.

Agarwal, S, Kulshreshtha, P, Bambah Mukku, D \& Bhatnagar, R. (2008). Alpha-enolase binds to human plasminogen on the surface of Bacillus anthracis. Biochim Biophys Acta, 1784, 986-94.

Agarwal, V, Kuchipudi, A, Fulde, M, Riesbeck, K, Bergmann, S \& Blom, AM. (2013). Streptococcus pneumoniae endopeptidase $\mathrm{O}(\mathrm{PepO})$ is a multifunctional plasminogen- and fibronectin-binding protein, facilitating evasion of innate immunity and invasion of host cells. J Biol Chem, 288, 6849-63.

Attali, C, Durmort, C, Vernet, T \& Di Guilmi, AM. (2008a). The interaction of Streptococcus pneumoniae with plasmin mediates transmigration across endothelial and epithelial monolayers by intercellular junction cleavage. Infect Immun, 76, 5350-6.

Attali, C, Frolet, C, Durmort, C, Offant, J, Vernet, T \& Di Guilmi, AM. (2008b). Streptococcus pneumoniae choline-binding protein $\mathrm{E}$ interaction with plasminogen/plasmin stimulates migration across the extracellular matrix. Infect Immun, 76, 466-76.

Barthel, D, Singh, B, Riesbeck, K \& Zipfel, PF. (2012). Haemophilus influenzae uses the surface protein E to acquire human plasminogen and to evade innate immunity. J Immunol, 188, 379-85.

Berge, A \& Sjobring, U. (1993). PAM, a novel plasminogen-binding protein from Streptococcus pyogenes. J Biol Chem, 268, 25417-24.

Bergmann, R, Dinkla, K, Nitsche-Schmitz, DP, Graham, RM, Luttge, M, Sanderson-Smith, ML, Nerlich, A, Rohde, M \& Chhatwal, GS. (2011). Biological functions of GCS3, a novel plasminogen-binding protein of Streptococcus dysgalactiae ssp. equisimilis. Int J Med Microbiol, 301, 157-64.

Bergmann, S, Rohde, M, Chhatwal, GS \& Hammerschmidt, S. (2001). Alpha-enolase of Streptococcus pneumoniae is a plasmin(ogen)-binding protein displayed on the bacterial cell surface. Mol Microbiol, 40, $1273-87$.

Bergmann, S, Rohde, M \& Hammerschmidt, S. (2004). Glyceraldehyde-3-phosphate dehydrogenase of Streptococcus pneumoniae is a surface-displayed plasminogen-binding protein. Infect Immun, 72, 2416-9.

Bergmann, S, Rohde, M, Preissner, KT \& Hammerschmidt, S. (2005). The nine residue plasminogen-binding motif of the pneumococcal enolase is the major cofactor of plasmin-mediated degradation of extracellular matrix, dissolution of fibrin and transmigration. Thromb Haemost, 94, 304-11.

Bergmann, S, Wild, D, Diekmann, O, Frank, R, Bracht, D, Chhatwal, GS \& Hammerschmidt, S. (2003). Identification of a novel plasmin(ogen)-binding motif in surface displayed alpha-enolase of Streptococcus pneumoniae. Mol Microbiol, 49, 411-23.

Bhattacharya, S, Ploplis, VA \& Castellino, FJ. Bacterial plasminogen receptors utilize host plasminogen system for effective invasion and dissemination. (2012). J Biomed Biotechnol, 482096.

Bigham, MT, Brady, PW, Manning, PB, Jacobs, BR, Kimball, TR \& Wong HR. (2008). Therapeutic application of intrapericardial tissue plasminogen activator in a 4-month-old child with complex fibropurulent pericarditis. Pediatr Crit Care Med, 9, e1-4.

Binder, A, Endler, G, Muller, M, Mannhalter, C, Zenz, W; European Meningococcal Study Group. (2007). 4G4G genotype of the plasminogen activator inhibitor-1 promoter polymorphism associates with disseminated intravascular coagulation in children with systemic meningococcemia. J Thromb Haemost, 5, 2049-54.

Blasi, F, Stoppelli, MP \& Cubellis, MV. (1986). The receptor for urokinase-plasminogen activator. J Cell Biochem, 32, 179-86.

Boël, G, Jin, H \& Pancholi, V. (2005). Inhibition of cell surface export of group A streptococcal anchorless surface dehydrogenase affects bacterial adherence and antiphagocytic properties. Infect Immun, 73, 6237-48.

Braff, MH, Jones, AL, Skerrett, SJ \& Rubens, CE. (2007). Staphylococcus aureus exploits cathelicidin antimicrobial peptides produced during early pneumonia to promote staphylokinase-dependent fibrinolysis. J Infect Dis, 195, 1365-72. 
Brissette, CA, Haupt, K, Barthel, D, Cooley, AE, Bowman, A, Skerka, C, Wallich, R, Zipfel, PF, Kraiczy, P \& Stevenson, B. (2009). Borrelia burgdorferi infection-associated surface proteins ErpP, ErpA, and ErpC bind human plasminogen. Infect Immun, 77, 300-6.

Brouwer, MC, Meijers, JC, Baas, F, van der Ende, A, Pfister, HW, Giese, A, van de Beek, D \& Koedel, U. (2014). Plasminogen activator inhibitor-1 influences cerebrovascular complications and death in pneumococcal meningitis. Acta Neuropathol, 124, 553-64.

Bugge, TH, Flick, MJ, Danton, MJ, Daugherty, CC, Romer, J, Dano, K, Carmeliet, P, Collen, D \& Degen, JL. (1996a). Urokinase-type plasminogen activator is effective in fibrin clearance in the absence of its receptor or tissue-type plasminogen activator. Proc Natl Acad Sci U S A, 93, 5899-904.

Bugge, TH, Kombrinck, KW, Flick, MJ, Daugherty, CC, Danton, MJ \& Degen, JL. (1996b). Loss of fibrinogen rescues mice from the pleiotropic effects of plasminogen deficiency. Cell, 87, 709-19.

Caballero, AR, Lottenberg, R \& Johnston, KH. (1999). Cloning, expression, sequence analysis, and characterization of streptokinases secreted by porcine and equine isolates of Streptococcus equisimilis. Infect Immun, 67, 6478-86.

Carmeliet, P, Schoonjans, L, Kieckens, L, Ream, B, Degen, J, Bronson, R, De Vos, R, Van Den Oord, JJ, Collen, D \& Mulligan, RC. (1994). Physiological consequences of loss of plasminogen activator gene function in mice. Nature, 368, 419-24.

Castellino, FJ \& Ploplis, VA. (2005). Structure and function of the plasminogen/plasmin system. Thromb Haemost, 93, 647-54.

Cederholm-Williams, SA, De Cock, F, Lijnen, HR \& Collen, D. (1979). Kinetics of the reactions between streptokinase, plasmin and alpha 2-antiplasmin. Eur J Biochem, 100, 125-32.

Chapman, HA. (1997). Plasminogen activators, integrins, and the coordinated regulation of cell adhesion and migration. Curr Opin Cell Biol, 9, 714-24.

Cheng, AG, McAdow, M, Kim, HK, Bae, T, Missiakas, DM \& Schneewind, O. (2010). Contribution of coagulases towards Staphylococcus aureus disease and protective immunity. PLoS Pathog, 6, e1001036.

Chhatwal, GS. (2002). Anchorless adhesins and invasins of Gram-positive bacteria: a new class of virulence factors. Trends MicrobioL, 10, 205-8.

Chumchua, V, Pornputtapong, N, Thammarongtham, C \& Meksuriyen D. (2008). Homology modeling of Mycoplasma pneumoniae enolase and its molecular interaction with human plasminogen. Bioinformation, 3, 18-23.

Chung, MC, Jorgensen, SC, Popova, TG, Tonry, JH, Bailey, CL \& Popov, SG. (2009). Activation of plasminogen activator inhibitor implicates protease $\operatorname{Inh} A$ in the acute-phase response to Bacillus anthracis infection. J Med Microbiol, 58, 737-44.

Chung, MC, Tonry, JH, Narayanan, A, Manes, NP, Mackie, RS, Gutting, B, Mukherjee, DV, Popova, TG, Kashanchi, F, Bailey, CL \& Popov, SG. (2011). Bacillus anthracis interacts with plasmin(ogen) to evade C3b-dependent innate immunity. PLoS One, 6, e18119.

Clinton, SR, Bina, JE, Hatch, TP, Whitt, MA \& Miller, MA. (2010). Binding and activation of host plasminogen on the surface of Francisella tularensis. BMC Microbiol, 10, 76.

Cole, JN, McArthur, JD, McKay, FC, Sanderson-Smith, ML, Cork, AJ, Ranson, M, Rohde, M, Itzek, A, Sun, H, Ginsburg, D, Kotb, M, Nizet, V, Chhatwal, GS \& Walker, MJ. (2006). Trigger for group A streptococcal M1T1 invasive disease. FASEB J, 20, 1745-7.

Coleman, DC, Sullivan, DJ, Russell, RJ, Arbuthnott, JP, Carey, BF \& Pomeroy, HM. (1989). Staphylococcus aureus bacteriophages mediating the simultaneous lysogenic conversion of beta-lysin, staphylokinase and enterotoxin A: molecular mechanism of triple conversion. J Gen Microbiol, 135, 1679-97.

Coleman, JL \& Benach, JL. (2000). The generation of enzymatically active plasmin on the surface of spirochetes. Methods, 21, 133-41.

Coleman, JL, Gebbia, JA, Piesman, J, Degen, JL, Bugge, TH \& Benach, JL. (1997). Plasminogen is required for efficient dissemination of $B$. burgdorferi in ticks and for enhancement of spirochetemia in mice. Cell, 89, 1111-9.

Coleman, JL, Roemer, EJ \& Benach, JL. (1999). Plasmin-coated borrelia Burgdorferi degrades soluble and insoluble components of the mammalian extracellular matrix. Infect Immun, 67, 3929-36.

Coleman, JL, Sellati, TJ, Testa, JE, Kew, RR, Furie, MB \& Benach, JL. (1995). Borrelia burgdorferi binds plasminogen, resulting in enhanced penetration of endothelial monolayers. Infect Immun, 63, 247884.

Collen, D. (1998). Staphylokinase: a potent, uniquely fibrin-selective thrombolytic agent. Nat Med, 4, $279-84$. 
Collen, D, Schlott, B, Engelborghs, Y, Van Hoef, B, Hartmann, M, Lijnen, HR \& Behnke, D. (1993). On the mechanism of the activation of human plasminogen by recombinant staphylokinase. J Biol Chem, 268, 8284-9.

Colucci, M \& Semeraro, N. (2012). Thrombin activatable fibrinolysis inhibitor: at the nexus of fibrinolysis and inflammation. Thromb Res, 129, 314-9.

Cook, SM, Skora, A, Gillen, CM, Walker, MJ \& McArthur, JD. (2012). Streptokinase variants from Streptococcus pyogenes isolates display altered plasminogen activation characteristics - implications for pathogenesis. Mol Microbiol, 86, 1052-62.

Cook, SM, Skora, A, Walker, MJ, Sanderson-Smith, ML \& McArthur, JD. (2014). Site-restricted plasminogen activation mediated by group A streptococcal streptokinase variants. Biochem J, 458, 23-31.

Crane, DD, Warner, SL \& Bosio, CM. (2009). A novel role for plasmin-mediated degradation of opsonizing antibody in the evasion of host immunity by virulent, but not attenuated, Francisella tularensis. J Immunol, 183, 4593-600.

Dale, JB, Fischetti, VA, Carapetis, JR, Steer, AC, Sow, S, Kumar, R, Mayosi, BM, Rubin, FA, Mulholland, K, Hombach, JM, Schödel, F \& Henao-Restrepo, AM. (2013). Group A streptococcal vaccines: paving a path for accelerated development. Vaccine, 31 Suppl 2, B216-22.

Declerck, PJ \& Gils, A. (2013). Three decades of research on plasminogen activator inhibitor-1: a multifaceted serpin. Semin Thromb Hemost, 39, 356-64.

Degen, JL, Bugge, TH \& Goguen, JD. (2007). Fibrin and fibrinolysis in infection and host defense. J Thromb Haemost, 5 Suppl 1, 24-31.

Del Rosso, M, Fibbi, G, Pucci, M, Margheri, F \& Serrati, S. (2008). The plasminogen activation system in inflammation. Front Biosci, 13, 4667-86.

Delvaeye, M \& Conway, EM. (2009). Coagulation and innate immune responses: can we view them separately? Blood, 114, 2367-74.

Di Micco, B, Di Micco, P, Lepretti, M, Stiuso, P, Donnarumma, G, lovene, MR, Capasso, R \& Tufano, MA. (2005). Hyperproduction of fibrin and inefficacy of antithrombin III and alpha2 macroglobulin in the presence of bacterial porins. Int J Exp Pathol, 86, 241-5.

Eberhard, T, Kronvall, G \& Ullberg, M. (1999). Surface bound plasmin promotes migration of Streptococcus pneumoniae through reconstituted basement membranes. Microb Pathog, 26, 175-81.

Egea, L, Aguilera, L, Gimenez, R, Sorolla, MA, Aguilar, J, Badia, J \& Baldoma, L. (2007). Role of secreted glyceraldehyde-3-phosphate dehydrogenase in the infection mechanism of enterohemorrhagic and enteropathogenic Escherichia coli: interaction of the extracellular enzyme with human plasminogen and fibrinogen. Int J Biochem Cell Biol, 39, 1190-203.

Ehinger, S, Schubert, WD, Bergmann, S, Hammerschmidt, S \& Heinz, DW. (2004). Plasmin(ogen)-binding alphaenolase from Streptococcus pneumoniae: crystal structure and evaluation of plasmin(ogen)-binding sites. J Mol Biol, 343, 997-1005.

Erova, TE, Rosenzweig, JA, Sha, J, Suarez, G, Sierra, JC, Kirtley, ML, van Lier, CJ, Telepnev, MV, Motin, VL \& Chopra AK. (2013). Evaluation of protective potential of Yersinia pestis outer membrane protein antigens as possible candidates for a new-generation recombinant plague vaccine. Clin Vaccine Immunol, 20, 227-38.

Esgleas, M, Li, Y, Hancock, MA, Harel, J, Dubreuil, JD \& Gottschalk, M. (2008). Isolation and characterization of alpha-enolase, a novel fibronectin-binding protein from Streptococcus suis. Microbiology, 154, 266879.

Flick, MJ, Du, X \& Degen, JL. (2004a). Fibrin(ogen)-alpha M beta 2 interactions regulate leukocyte function and innate immunity in vivo. Exp Biol Med (Maywood), 229, 1105-10.

Flick, MJ, Du, X, Witte, DP, Jirouskova, M, Soloviev, DA, Busuttil, SJ, Plow, EF \& Degen, JL (2004b). Leukocyte engagement of fibrin(ogen) via the integrin receptor alphaMbeta2/Mac-1 is critical for host inflammatory response in vivo. J Clin Invest, 113, 1596-606.

Floden, AM, Watt, JA \& Brissette, CA (2011). Borrelia burgdorferi enolase is a surface-exposed plasminogen binding protein. PLoS One, 6, e27502.

Fu, Q, Figuera-Losada, M, Ploplis, VA, Cnudde, S, Geiger, JH, Prorok, M \& Castellino, FJ. (2008). The lack of binding of VEK-30, an internal peptide from the group A streptococcal M-like protein, PAM, to murine plasminogen is due to two amino acid replacements in the plasminogen kringle-2 domain. J Biol Chem, 283, 1580-7.

Fuchs, H., Simon, M. M., Wallich, R., Bechtel, M. \& Kramer, M. D. (1996). Borrelia burgdorferi induces secretion of pro-urokinase-type plasminogen activator by human monocytes. Infect Immun, 64, 4307-12. 
Fuchs, H, Wallich, R, Simon, MM \& Kramer, MD. (1994). The outer surface protein A of the spirochete Borrelia burgdorferi is a plasmin(ogen) receptor. Proc Natl Acad Sci U S A, 91, 12594-8.

Gardiner, EE \& Medcalf, RL. (2014). Is PAI-2 really a PAI after all? J Thromb Haemost.

Gebbia, JA, Monco, JC, Degen, JL, Bugge, TH \& Benach, JL. (1999). The plasminogen activation system enhances brain and heart invasion in murine relapsing fever borreliosis. J Clin Invest, 103, 81-7.

Goguen, JD, Bugge, T \& Degen, JL. (2000). Role of the pleiotropic effects of plasminogen deficiency in infection experiments with plasminogen-deficient mice. Methods, 21, 179-83.

Grab, DJ, Perides, G, Dumler, JS, Kim, KJ, Park, J, Kim, YV, Nikolskaia, O, Choi, KS, Stins, MF \& Kim, KS. (2005). Borrelia burgdorferi, host-derived proteases, and the blood-brain barrier. Infect Immun, 73, 1014-22.

Gray, B, Hall, P \& Gresham H. (2013). Targeting agr- and agr-Like quorum sensing systems for development of common therapeutics to treat multiple gram-positive bacterial infections. Sensors, 13, 5130-66.

Green, J, Doughty, L, Kaplan, SS, Sasser, H \& Carcillo, JA. (2002). The tissue factor and plasminogen activator inhibitor type-1 response in pediatric sepsis-induced multiple organ failure. Thromb Haemost, 87, 218-23.

Grosskinsky, S, Schott, M, Brenner, C, Cutler, SJ, Kraiczy, P, Zipfel, PF, Simon, MM \& Wallich, R (2009). Borrelia recurrentis employs a novel multifunctional surface protein with anti-complement, anti-opsonic and invasive potential to escape innate immunity. PLoS One, 4, e4858.

Guo, Y, Li, J, Hagstrom, E \& Ny, T. (2011). Beneficial and detrimental effects of plasmin(ogen) during infection and sepsis in mice. PLoS One, 6, e24774.

Haiko, J, Laakkonen, L, Juuti, K, Kalkkinen, N \& Korhonen, TK. (2010). The omptins of Yersinia pestis and Salmonella enterica cleave the reactive center loop of plasminogen activator inhibitor 1 . J Bacteriol, 192, 4553-61.

Haiko, J, Suomalainen, M, Ojala, T, Lahteenmaki, K \& Korhonen, TK. (2009). Invited review: Breaking barriers-attack on innate immune defences by omptin surface proteases of enterobacterial pathogens. Innate Immun, 15, 67-80.

Haile, WB, Coleman, JL \& Benach, JL. (2006). Reciprocal upregulation of urokinase plasminogen activator and its inhibitor, PAI-2, by Borrelia burgdorferi affects bacterial penetration and host-inflammatory response. Cell Microbiol, 8, 1349-60.

Hall, SW, Humphries, JE \& Gonias, SL. (1991). Inhibition of cell surface receptor-bound plasmin by alpha 2antiplasmin and alpha 2-macroglobulin. J Biol Chem, 266, 12329-36.

Hallstrom, T, Haupt, K, Kraiczy, P, Hortschansky, P, Wallich, R, Skerka, C \& Zipfel, PF. (2010). Complement regulator-acquiring surface protein 1 of Borrelia burgdorferi binds to human bone morphogenic protein 2, several extracellular matrix proteins, and plasminogen. J Infect Dis, 202, 490-8.

Hammerschmidt, C, Koenigs, A, Siegel, C, Hallstrom, T, Skerka, C, Wallich, R, Zipfel, PF \& Kraiczy, P. (2014). Versatile roles of CspA orthologs in complement inactivation of serum-resistant Lyme disease spirochetes. Infect Immun, 82, 380-92.

Hemmelgarn, BR, Moist, LM, Lok, CE, Tonelli, M, Manns, BJ, Holden, RM, LeBlanc, M, Faris, P, Barre, P, Zhang, J \& Scott-Douglas, N. (2011). Prevention of dialysis catheter malfunction with recombinant tissue plasminogen activator. N Engl J Med, 364, 303-12.

Hoogerwerf, JJ, De Vos, AF, Levi, M, Bresser, P, Van Der Zee, JS, Draing, C, Von Aulock, S \& Van Der Poll, T. (2009). Activation of coagulation and inhibition of fibrinolysis in the human lung on bronchial instillation of lipoteichoic acid and lipopolysaccharide. Crit Care Med, 37, 619-25.

Hu, LT., Pratt, SD, Perides, G, Katz, L, Rogers, RA \& Klempner, MS. (1997). Isolation, cloning, and expression of a 70-kilodalton plasminogen binding protein of Borrelia burgdorferi. Infect Immun, 65, 4989-95.

Humphreys, H, Keane, CT, Hone, R, Pomeroy, H, Russell, RJ, Arbuthnott, JP \& Coleman, DC. (1989). Enterotoxin production by Staphylococcus aureus isolates from cases of septicaemia and from healthy carriers. J Med Microbiol, 28, 163-72.

Innes, A, Burden, RP, Finch, RG \& Morgan, AG. (1994). Treatment of resistant peritonitis in continuous ambulatory peritoneal dialysis with intraperitoneal urokinase: a double-blind clinical trial. Nephrol Dial Transplant, 9, 797-9.

Jarvinen, HM, Laakkonen, L, Haiko, J, Johansson, T, Juuti, K, Suomalainen, M, Buchrieser, C, Kalkkinen, N \& Korhonen, TK. (2013). Human single-chain urokinase is activated by the omptins PgtE of Salmonella enterica and Pla of Yersinia pestis despite mutations of active site residues. Mol Microbiol, 89, 507-17.

Jin, T, Bokarewa, M, Foster, T, Mitchell, J, Higgins, J \& Tarkowski, A. (2004). Staphylococcus aureus resists human defensins by production of staphylokinase, a novel bacterial evasion mechanism. J Immunol, $172,1169-76$. 
Jones, MN \& Holt, RG. (2004). Activation of plasminogen by Streptococcus mutans. Biochem Biophys Res Commun, 322, 37-41.

Jones, MN \& Holt, RG. (2007). Cloning and characterization of an alpha-enolase of the oral pathogen Streptococcus mutans that binds human plasminogen. Biochem Biophys Res Commun, 364, 924-9.

Kager, LM, Weehuizen, TA, Wiersinga, WJ, Roelofs, JJ, Meijers, JC, Dondorp, AM, Van 'T Veer, C \& Van Der Poll, T. (2013). Endogenous alpha2-antiplasmin is protective during severe gram-negative sepsis (melioidosis). Am J Respir Crit Care Med, 188, 967-75.

Kager, LM, Wiersinga, WJ, Roelofs, JJ, Meijers, JC, Levi, M, Van't Veer, C \& Van Der Poll, T. (2011). Plasminogen activator inhibitor type I contributes to protective immunity during experimental Gram-negative sepsis (melioidosis). J Thromb Haemost, 9, 2020-8.

Kager, LM, Wiersinga, WJ, Roelofs, JJ, Meijers, JC, Levi, M, Van't Veer, C \& Van Der Poll, T. (2012). Endogenous tissue-type plasminogen activator impairs host defense during severe experimental Gram-negative sepsis (melioidosis)*. Crit Care Med, 40, 2168-75.

Katayama, Y, Baba, T, Sekine, M, Fukuda, M \& Hiramatsu, K. (2013). Beta-hemolysin promotes skin colonization by Staphylococcus aureus. J Bacteriol, 195, 1194-203.

Kenny, S, Duval, C, Sammut, SJ, Steele, I, Pritchard, DM, Atherton, JC, Argent, RH, Dimaline, R, Dockray, GJ \& Varro, A. (2008). Increased expression of the urokinase plasminogen activator system by Helicobacter pylori in gastric epithelial cells. Am J Physiol Gastrointest Liver Physiol, 295, G431-41.

Khil, J, Im, M, Heath, A, Ringdahl, U, Mundada, L, Cary Engleberg, N \& Fay, WP. (2003). Plasminogen enhances virulence of group A streptococci by streptokinase-dependent and streptokinase-independent mechanisms. J Infect Dis, 188, 497-505.

Kinnby, B, Booth, NA \& Svensater, G. (2008). Plasminogen binding by oral streptococci from dental plaque and inflammatory lesions. Microbiology, 154, 924-31.

Kitadai, Y, Sasaki, A, Ito, M, Tanaka, S, Oue, N, Yasui, W, Aihara, M, Imagawa, K, Haruma, K \& Chayama, K. (2003). Helicobacter pylori infection influences expression of genes related to angiogenesis and invasion in human gastric carcinoma cells. Biochem Biophys Res Commun, 311, 809-14.

Knaust, A, Weber, MV, Hammerschmidt, S, Bergmann, S, Frosch, M \& Kurzai, O. (2007). Cytosolic proteins contribute to surface plasminogen recruitment of Neisseria meningitidis. J Bacteriol, 189, 3246-55.

Koch, TK, Reuter, M, Barthel, D, Bohm, S, Van Den Elsen, J, Kraiczy, P, Zipfel, PF \& Skerka, C. (2012). Staphylococcus aureus proteins Sbi and Efb recruit human plasmin to degrade complement $\mathrm{C} 3$ and C3b. PLoS One, 7, e47638.

Koenigs, A, Hammerschmidt, C, Jutras, BL, Pogoryelov, D, Barthel, D, Skerka, C, Kugelstadt, D, Wallich, R, Stevenson, B., Zipfel, P. F. \& Kraiczy, P. (2013). BBA70 of Borrelia burgdorferi is a novel plasminogenbinding protein. J Biol Chem, 288, 25229-43.

Korhonen, TK, Haiko, J, Laakkonen, L, Jarvinen, HM \& Westerlund-Wikstrom, B. (2013). Fibrinolytic and coagulative activities of Yersinia pestis. Front Cell Infect Microbiol, 3, 35.

Kukkonen, M, Lahteenmaki, K, Suomalainen, M, Kalkkinen, N, Emody, L, Lang, H \& Korhonen, TK. (2001). Protein regions important for plasminogen activation and inactivation of alpha2-antiplasmin in the surface protease Pla of Yersinia pestis. Mol Microbiol, 40, 1097-111.

Kukkonen, M, Saarela, S, Lahteenmaki, K, Hynonen, U, Westerlund-Wikstrom, B, Rhen, M \& Korhonen, TK. (1998). Identification of two laminin-binding fimbriae, the type 1 fimbria of Salmonella enterica serovar typhimurium and the $\mathrm{G}$ fimbria of Escherichia coli, as plasminogen receptors. Infect Immun, 66, 4965-70.

Kuusela, P \& Saksela, O. (1990). Binding and activation of plasminogen at the surface of Staphylococcus aureus. Increase in affinity after conversion to the Lys form of the ligand. Eur J Biochem, 193, 759-65.

Kwiecinski, J, Peetermans, M, Liesenborghs, L, Josefsson, E, Verhamme, P \& Jin, T. 2014. Staphylokinase regulates Staphylococcus aureus biofilm formation by activating host's plasminogen: a new therapeutic modality for preventing biofilm infections. International Symposium on Staphylococci and Staphylococcal Infections. Chicago.

Kwiecinski, J, Jacobsson, G, Karlsson, M, Zhu, X, Wang, W, Bremell, T, Josefsson, E \& Jin, T (2013). Staphylokinase Promotes the Establishment of Staphylococcus aureus Skin Infections While Decreasing Disease Severity. J Infect Dis, 208, 990-9.

Kwiecinski, J, Josefsson, E, Mitchell, J, Higgins, J, Magnusson, M, Foster, T, Jin, T \& Bokarewa, M. (2010). Activation of plasminogen by staphylokinase reduces the severity of Staphylococcus aureus systemic infection. J Infect Dis, 202, 1041-9.

Lagal, V, Portnoi, D, Faure, G, Postic, D \& Baranton, G. (2006). Borrelia burgdorferi sensu stricto invasiveness is correlated with OspC-plasminogen affinity. Microbes Infect, 8, 645-52. 
Lahteenmaki, K, Kuusela, P \& Korhonen, TK. (2001). Bacterial plasminogen activators and receptors. FEMS Microbiol Rev, 25, 531-52.

Lahteenmaki, K, Virkola, R, Pouttu, R, Kuusela, P, Kukkonen, M \& Korhonen, TK. (1995). Bacterial plasminogen receptors: in vitro evidence for a role in degradation of the mammalian extracellular matrix. Infect Immun, 63, 3659-64.

Lahteenmaki, K, Virkola, R, Saren, A, Emody, L \& Korhonen, TK. (1998). Expression of plasminogen activator pla of Yersinia pestis enhances bacterial attachment to the mammalian extracellular matrix. Infect Immun, 66, 5755-62.

Lahteenmaki, K, Westerlund, B, Kuusela, P \& Korhonen, TK. (1993). Immobilization of plasminogen on Escherichia coli flagella. FEMS Microbiol Lett, 106, 309-14.

Lama, A, Kucknoor, A, Mundodi, V \& Alderete, JF. (2009). Glyceraldehyde-3-phosphate dehydrogenase is a surface-associated, fibronectin-binding protein of Trichomonas vaginalis. Infect Immun, 77, 2703-11.

Lathem, WW, Price, PA, Miller, VL \& Goldman, WE. (2007). A plasminogen-activating protease specifically controls the development of primary pneumonic plague. Science, 315, 509-13.

Laufs, S, Schumacher, J \& Allgayer, H. (2006). Urokinase-receptor (u-PAR): an essential player in multiple games of cancer: a review on its role in tumor progression, invasion, metastasis, proliferation/dormancy, clinical outcome and minimal residual disease. Cell Cycle, 5, 1760-71.

Law, RH, Abu-Ssaydeh, D \& Whisstock, JC. (2013). New insights into the structure and function of the plasminogen/plasmin system. Curr Opin Struct Biol, 23, 836-41.

Leigh, JA, Hodgkinson, SM \& Lincoln, RA. (1998). The interaction of Streptococcus dysgalactiae with plasmin and plasminogen. Vet Microbiol, 61, 121-35.

Levi, M \& Van Der Poll, T. (2010). Inflammation and coagulation. Crit Care Med, 38, S26-34.

Levitas, A, Krymko, H, Richardson, J, Zalzstein, E \& loffe, V. (2015). Recombinant tissue plasminogen activator as a novel treatment option for infective endocarditis: a retrospective clinical study in 32 children. Cardiol Young, 1-6.

Li, L, Nie, W, Zhou, H, Yuan, W, Li, W \& Huang, W. (2013). Association between plasminogen activator inhibitor-1 -675 4G/5G polymorphism and sepsis: a meta-analysis. PLoS One, 8, e54883.

Li, Z, Ploplis, VA, French, EL \& Boyle, MD. (1999). Interaction between group A streptococci and the plasmin(ogen) system promotes virulence in a mouse skin infection model. J Infect Dis, 179, 907-14.

Lijnen, HR. (2005). Pleiotropic functions of plasminogen activator inhibitor-1. J Thromb Haemost, 3, 35-45.

Lijnen, HR \& Collen, D. (1988). Mechanisms of plasminogen activation by mammalian plasminogen activators. Enzyme, 40, 90-6.

Lijnen, HR, Van Hoef, B, De Cock, F, Okada, K, Ueshima, S, Matsuo, O \& Collen, D. (1991). On the mechanism of fibrin-specific plasminogen activation by staphylokinase. J Biol Chem, 266, 11826-32.

Lim, JH, Woo, CH \& Li, JD. (2011). Critical role of type 1 plasminogen activator inhibitor (PAI-1) in early host defense against nontypeable Haemophilus influenzae (NTHi) infection. Biochem Biophys Res Commun, 414, 67-72.

Lorente, L, Martin, MM, Borreguero-Leon, JM, Sole-Violan, J, Ferreres, J, Labarta, L, Diaz, C, Jimenez, A \& Paramo, JA. (2014). Sustained high plasma plasminogen activator inhibitor-1 levels are associated with severity and mortality in septic patients. Thromb Res, 134, 182-6.

Luedicke, C, Slickers, P, Ehricht, R \& Monecke, S. (2010). Molecular fingerprinting of Staphylococcus aureus from bone and joint infections. Eur J Clin Microbiol Infect Dis, 29, 457-63.

Luo, D, Lin, JS, Parent, MA, Mullarky-Kanevsky, I, Szaba, FM, Kummer, LW, Duso, DK, Tighe, M, Hill, J, Gruber, A, Mackman, N, Gailani, D \& Smiley, ST. (2013). Fibrin facilitates both innate and T cell-mediated defense against Yersinia pestis. J Immunol, 190, 4149-61.

Luo, D, Szaba, FM, Kummer, LW, Plow, EF, Mackman, N, Gailani, D \& Smiley, ST. (2011). Protective roles for fibrin, tissue factor, plasminogen activator inhibitor-1, and thrombin activatable fibrinolysis inhibitor, but not factor $\mathrm{XI}$, during defense against the gram-negative bacterium Yersinia enterocolitica. J Immunol, 187, 1866-76.

Ly, D, Taylor, JM, Tsatsaronis, JA, Monteleone, MM, Skora, AS, Donald, CA, Maddocks, T, Nizet, V, West, NP, Ranson, M, Walker, MJ, McArthur, JD \& Sanderson-Smith, ML. (2014). Plasmin(ogen) acquisition by group A Streptococcus protects against C3b-mediated neutrophil killing. J Innate Immun, 6, 240-50.

Madoiwa, S, Nunomiya, S, Ono, T, Shintani, Y, Ohmori, T, Mimuro, J \& Sakata, Y. (2006). Plasminogen activator inhibitor 1 promotes a poor prognosis in sepsis-induced disseminated intravascular coagulation. Int J Hematol, 84, 398-405. 
Magalhaes, V, Andrade, EB, Alves, J, Ribeiro, A, Kim, KS, Lima, M, Trieu-Cuot, P \& Ferreira, P. (2013). Group B Streptococcus hijacks the host plasminogen system to promote brain endothelial cell invasion. PLoS One, 8, e63244.

Magalhaes, V, Veiga-Malta, I, Almeida, MR, Baptista, M, Ribeiro, A, Trieu-Cuot, P \& Ferreira, P. (2007). Interaction with human plasminogen system turns on proteolytic activity in Streptococcus agalactiae and enhances its virulence in a mouse model. Microbes Infect, 9, 1276-84.

Makowski, GS \& Ramsby, ML. (1998). Binding of latent matrix metalloproteinase 9 to fibrin: activation via a plasmin-dependent pathway. Inflammation, 22, 287-305.

Mandl-Weber, S, Haslinger, B, Lederer, SR \& Sitter, T. (2001). Heat-killed microorganisms induce PAI-1 expression in human peritoneal mesothelial cells: role of interleukin-1alpha. Am J Kidney Dis, 37, 8159.

Masuya, K, Okada, H, Imai, T, Isobe, K \& Itoh, S. (2006). A case of intractable methicillin-resistant Staphylococcus aureus sepsis after an operation for tetralogy of Fallot that was successfully resolved by combined treatment with vancomycin and urokinase. Pediatr Int, 48, 163-5.

Matta, SK, Agarwal, S \& Bhatnagar, R. (2010). Surface localized and extracellular Glyceraldehyde-3-phosphate dehydrogenase of Bacillus anthracis is a plasminogen binding protein. Biochim Biophys Acta, 1804, 2111-20.

McAdow, M, Kim, HK, Dedent, AC, Hendrickx, AP, Schneewind, O \& Missiakas, DM. (2011). Preventing Staphylococcus aureus sepsis through the inhibition of its agglutination in blood. PLoS Pathog, 7, e1002307.

McCoy, HE, Broder, CC \& Lottenberg, R. (1991). Streptokinases produced by pathogenic group C streptococci demonstrate species-specific plasminogen activation. J Infect Dis, 164, 515-21.

McKay, FC, McArthur, JD, Sanderson-Smith, ML, Gardam, S, Currie, BJ, Sriprakash, KS, Fagan, PK, Towers, RJ, Batzloff, MR, Chhatwal, GS, Ranson, M \& Walker, MJ. (2004). Plasminogen binding by group A streptococcal isolates from a region of hyperendemicity for streptococcal skin infection and a high incidence of invasive infection. Infect Immun, 72, 364-70.

McRitchie, DI, Girotti, MJ, Glynn, MF, Goldberg, JM \& Rotstein, OD. (1991). Effect of systemic fibrinogen depletion on intraabdominal abscess formation. J Lab Clin Med, 118, 48-55.

Miles, LA, Dahlberg, CM, Plescia, J, Felez, J, Kato, K \& Plow, EF (1991). Role of cell-surface lysines in plasminogen binding to cells: identification of alpha-enolase as a candidate plasminogen receptor. Biochemistry, 30, 1682-91.

Miles, LA \& Parmer, RJ. (2013). Plasminogen receptors: the first quarter century. Semin Thromb Hemost, 39, 329-37.

Mohan, S, Hertweck, C, Dudda, A, Hammerschmidt, S, Skerka, C, Hallstrom, T \& Zipfel, PF. (2014). Tuf of Streptococcus pneumoniae is a surface displayed human complement regulator binding protein. Mol Immunol, 62, 249-64.

Molkanen, T, Tyynela, J, Helin, J, Kalkkinen, N \& Kuusela, P. (2002). Enhanced activation of bound plasminogen on Staphylococcus aureus by staphylokinase. FEBS Lett, 517, 72-8.

Monea, S, Lehti, K, Keski-Oja, J \& Mignatti, P. (2002). Plasmin activates pro-matrix metalloproteinase-2 with a membrane-type 1 matrix metalloproteinase-dependent mechanism. J Cell Physiol, 192, 160-70.

Monecke, S, Berger-Bachi, B, Coombs, G, Holmes, A, Kay, I, Kearns, A, Linde, HJ, O'Brien, F, Slickers, P \& Ehricht, R. (2007). Comparative genomics and DNA array-based genotyping of pandemic Staphylococcus aureus strains encoding Panton-Valentine leukocidin. Clin Microbiol Infect, 13, 23649.

Monecke, S, Luedicke, C, Slickers, P \& Ehricht, R. (2009). Molecular epidemiology of Staphylococcus aureus in asymptomatic carriers. Eur J Clin Microbiol Infect Dis, 28, 1159-65.

Montes, R, Declerck, PJ, Calvo, A, Montes, M, Hermida, J, Munoz, MC \& Rocha, E. (2000). Prevention of renal fibrin deposition in endotoxin-induced DIC through inhibition of PAI-1. Thromb Haemost, 84, 65-70.

Mundodi, V, Kucknoor, AS \& Alderete, JF. (2008). Immunogenic and plasminogen-binding surface-associated alpha-enolase of Trichomonas vaginalis. Infect Immun, 76, 523-31.

Murphy, G, Ward, R, Gavrilovic, J \& Atkinson, S. (1992). Physiological mechanisms for metalloproteinase activation. Matrix Suppl, 1, 224-30.

Murray, EJ, Crowley, RC, Truman, A, Clarke, SR, Cottam, JA, Jadhav, GP, Steele, VR, O'Shea, P, Lindholm, C, Cockayne, A, Chhabra, SR, Chan, WC \& Williams, P. (2014). Targeting Staphylococcus aureus quorum sensing with nonpeptidic small molecule inhibitors. J Med Chem, 57, 2813-9. 
Muto, Y, Suzuki, K, lida, H, Sakakibara, S, Kato, E, Itoh, F, Kakui, N \& Ishii, H. (2009). EF6265, a novel inhibitor of activated thrombin-activatable fibrinolysis inhibitor, protects against sepsis-induced organ dysfunction in rats. Crit Care Med, 37, 1744-9.

Nickel, KF \& Renné, T. (2012). Crosstalk of the plasma contact system with bacteria. Thromb Res, 130 Suppl 1, S78-83.

Nogueira, SV, Smith, AA, Qin, JH \& Pal, U. (2012). A surface enolase participates in Borrelia burgdorferiplasminogen interaction and contributes to pathogen survival within feeding ticks. Infect Immun, 80 , 82-90.

Nordstrand, A, Shamaei-Tousi, A, Ny, A \& Bergstrom, S. (2001). Delayed invasion of the kidney and brain by Borrelia crocidurae in plasminogen-deficient mice. Infect Immun, 69, 5832-9.

Novick, RP. (2003). Autoinduction and signal transduction in the regulation of staphylococcal virulence. Mol Microbiol, 48, 1429-49.

Oehmcke, S, Shannon, O, von Köckritz-Blickwede, M, Mörgelin, M, Linder, A, Olin, Al, Björck, L, Herwald, H. (2009). Treatment of invasive streptococcal infection with a peptide derived from human highmolecular weight kininogen. Blood, 114, 444-51.

Otto, M. (2004). Virulence factors of the coagulase-negative staphylococci. Front Biosci, 9, 841-63.

Pancholi, V \& Fischetti, VA. (1992). A major surface protein on group A streptococci is a glyceraldehyde-3phosphate-dehydrogenase with multiple binding activity. J Exp Med, 176, 415-26.

Pancholi, V \& Fischetti, VA. (1998). Alpha-enolase, a novel strong plasmin(ogen) binding protein on the surface of pathogenic streptococci. J Biol Chem, 273, 14503-15.

Pancholi, V, Fontan, P \& Jin, H. (2003). Plasminogen-mediated group A streptococcal adherence to and pericellular invasion of human pharyngeal cells. Microb Pathog, 35, 293-303.

Pancholi, V \& Chhatwal, GS. (2003). Housekeeping enzymes as virulence factors for pathogens. Int J Med Microbiol, 293, 391-401.

Park, CG, Goh, YJ, Kook, SH, Park, HK, Kim, BJ, Cha, CY \& Kook, YH. (1997). Increased expression of urokinase type plasminogen activator(u-PA), plasminogen activator inhibitor-1(PAI-1), and collagenases in Caco2 cells infected by Salmonella typhimurium. J Korean Med Sci, 12, 23-31.

Parkkinen, J \& Korhonen, TK. (1989). Binding of plasminogen to Escherichia coli adhesion proteins. FEBS Lett, 250, 437-40.

Peetermans, M, Vanassche, T, Liesenborghs, L, Claes, J, Vande Velde, G, Kwiecinski, J, Jin, T, De Geest, B, Hoylaerts, MF, Lijnen, RH \& Verhamme, P. (2014). Plasminogen activation by staphylokinase enhances local spreading of $\mathrm{S}$. aureus in skin infections. BMC Microbiol, 14, 310.

Peetermans, M, Verhamme, P \& Vanassche, T. (2015). Coagulase Activity by Staphylococcus aureus: A Potential Target for Therapy? Semin Thromb Hemost, in press.

Piechowicz, L, Galin'ski, J, Garbacz, K \& Haras, K (2010). Bacteriophage analysis of staphylokinase-negative Staphylococcus aureus strains isolated from people. J Basic Microbiol, 50, 557-61.

Pralong, G, Calandra, T, Glauser, MP, Schellekens, J, Verhoef, J, Bachmann, F \& Kruithof, EK. (1989). Plasminogen activator inhibitor 1: a new prognostic marker in septic shock. Thromb Haemost, 61, 459-62.

Raaphorst, J, Johan Groeneveld, AB, Bossink, AW \& Erik Hack, C. (2001). Early inhibition of activated fibrinolysis predicts microbial infection, shock and mortality in febrile medical patients. Thromb Haemost, 86 , 543-9.

Raeven, P, Feichtinger, GA, Weixelbaumer, KM, Atzenhofer, S, Redl, H, Van Griensven, M, Bahrami, S \& Osuchowski, MF. (2012). Compartment-specific expression of plasminogen activator inhibitor-1 correlates with severity/outcome of murine polymicrobial sepsis. Thromb Res, 129, e238-45.

Ramu, P, Tanskanen, R, Holmberg, M, Lahteenmaki, K, Korhonen, TK \& Meri, S. (2007). The surface protease PgtE of Salmonella enterica affects complement activity by proteolytically cleaving C3b, C4b and C5. FEBS Lett, 581, 1716-20.

Renckens, R, Roelofs, JJ, Bonta, PI, Florquin, S, De Vries, CJ, Levi, M, Carmeliet, P, Van't Veer, C \& Van Der Poll, T. (2007). Plasminogen activator inhibitor type 1 is protective during severe Gram-negative pneumonia. Blood, 109, 1593-601.

Renckens, R, Roelofs, JJ, ter Horst, SA, van 't Veer, C, Havik, SR, Florquin, S, Wagenaar, GT, Meijers, JC \& van der Poll, T. (2011). Absence of thrombin-activatable fibrinolysis inhibitor protects against sepsisinduced liver injury in mice. J Immunol, 175, 6764-71.

Resch, G, Francois, P, Morisset, D, Stojanov, M, Bonetti, EJ, Schrenzel, J, Sakwinska, O \& Moreillon, P. (2013). Human-to-bovine jump of Staphylococcus aureus CC8 is associated with the loss of a beta-hemolysin 
converting prophage and the acquisition of a new staphylococcal cassette chromosome. PLoS One, 8 , e58187.

Reznikoff, CP, Fish, JT \& Coursin, DB. (2003). Pericardial infusion of tissue plasminogen activator in fibropurulent pericarditis. J Intensive Care Med, 18, 47-51.

Rijken, DC \& Lijnen, HR. (2009). New insights into the molecular mechanisms of the fibrinolytic system. J Thromb Haemost, 7, 4-13.

Ringdahl, U, Svensson, M, Wistedt, AC, Renne, T, Kellner, R, Muller-Esterl, W \& Sjobring, U. (1998). Molecular co-operation between protein PAM and streptokinase for plasmin acquisition by Streptococcus pyogenes. J Biol Chem, 273, 6424-30.

Rooijakkers, SH, Van Wamel, WJ, Ruyken, M, Van Kessel, KP \& Van Strijp, JA. (2005). Anti-opsonic properties of staphylokinase. Microbes Infect, 7, 476-84.

Rosey, EL, Lincoln, RA, Ward, PN, Yancey, RJ, Jr. \& Leigh, JA. (1999). PauA: a novel plasminogen activator from Streptococcus uberis. FEMS Microbiol Lett, 178, 27-33.

Rossmann, E, Kraiczy, P, Herzberger, P, Skerka, C, Kirschfink, M, Simon, MM, Zipfel, PF \& Wallich, R. (2007). Dual binding specificity of a Borrelia hermsii-associated complement regulator-acquiring surface protein for factor $\mathrm{H}$ and plasminogen discloses a putative virulence factor of relapsing fever spirochetes. J Immunol, 178, 7292-301.

Ruotsalainen, E, Karden-Lilja, M, Kuusela, P, Vuopio-Varkila, J, Virolainen-Julkunen, A, Sarna, S, Valtonen, V \& Jarvinen, A. (2008). Methicillin-sensitive Staphylococcus aureus bacteraemia and endocarditis among injection drug users and nonaddicts: host factors, microbiological and serological characteristics. J Infect, 56, 249-56.

Sanderson-Smith, ML, Dinkla, K, Cole, JN, Cork, AJ, Maamary, PG, McArthur, JD, Chhatwal, GS \& Walker, MJ. (2008). M protein-mediated plasminogen binding is essential for the virulence of an invasive Streptococcus pyogenes isolate. FASEB J, 22, 2715-22.

Sanderson-Smith, ML, De Oliveira, DM, Ranson, M \& McArthur, JD. (2012). Bacterial plasminogen receptors: mediators of a multifaceted relationship. J Biomed Biotechnol, 2012, 272148.

Sanderson-Smith, ML, Zhang, Y, Ly, D, Donahue, D, Hollands, A, Nizet, V, Ranson, M, Ploplis, VA, Walker, MJ \& Castellino, FJ. (2013). A key role for the urokinase plasminogen activator (UPA) in invasive Group A streptococcal infection. PLoS Pathog, 9, e1003469.

Santala, A, Saarinen, J, Kovanen, P \& Kuusela, P. (1999). Activation of interstitial collagenase, MMP-1, by Staphylococcus aureus cells having surface-bound plasmin: a novel role of plasminogen receptors of bacteria. FEBS Lett, 461, 153-6.

Sato, J, Schorey, J, Ploplis, VA, Haalboom, E, Krahule, L \& Castellino, FJ. (2003). The fibrinolytic system in dissemination and matrix protein deposition during a mycobacterium infection. Am J Pathol, 163, 517-31.

Scheiblhofer, S, Weiss, R, Dürnberger, H, Mostböck, S, Breitenbachn-, M, Livey, I \& Thalhamer, J. (2003). A DNA vaccine encoding the outer surface protein $C$ from Borrelia burgdorferi is able to induce protective immune responses. Microbes Infect, 5, 939-46.

Schlichting, E, Lyberg, T, Solberg, O \& Andersen, BM. (1993). Endotoxin liberation from Neisseria meningitidis correlates to their ability to induce procoagulant and fibrinolytic factors in human monocytes. Scand J Infect Dis, 25, 585-94.

Schuster, V, Hugle, B \& Tefs, K. (2007). Plasminogen deficiency. J Thromb Haemost, 5, 2315-22.

Sebbane, F, Jarrett, CO, Gardner, D, Long, D \& Hinnebusch, BJ. (2006). Role of the Yersinia pestis plasminogen activator in the incidence of distinct septicemic and bubonic forms of flea-borne plague. Proc Natl Acad Sci U S A, 103, 5526-30.

Seifert, KN, McArthur, WP, Bleiweis, AS \& Brady, LJ. (2003). Characterization of group B streptococcal glyceraldehyde-3-phosphate dehydrogenase: surface localization, enzymatic activity, and proteinprotein interactions. Can J Microbiol, 49, 350-6.

Sha, J, Erova, TE, Alyea, RA, Wang, S, Olano, JP, Pancholi, V \& Chopra, AK. (2009). Surface-expressed enolase contributes to the pathogenesis of clinical isolate SSU of Aeromonas hydrophila. J Bacteriol, 191, 3095-107.

Siemens, N, Patenge, N, Otto, J, Fiedler, T \& Kreikemeyer, B. (2011). Streptococcus pyogenes M49 plasminogen/plasmin binding facilitates keratinocyte invasion via integrin-integrin-linked kinase (ILK) pathways and protects from macrophage killing. J Biol Chem, 286, 21612-22.

Sijbrandi, R, Den Blaauwen, T, Tame, JR, Oudega, B, Luirink, J \& Otto, BR. (2005). Characterization of an ironregulated alpha-enolase of Bacteroides fragilis. Microbes Infect, 7, 9-18. 
Silence, K, Collen, D \& Lijnen, HR. (1993). Interaction between staphylokinase, plasmin(ogen), and alpha 2antiplasmin. Recycling of staphylokinase after neutralization of the plasmin-staphylokinase complex by alpha 2-antiplasmin. J Biol Chem, 268, 9811-6.

Sjobring, U, Pohl, G \& Olsen, A. (1994). Plasminogen, absorbed by Escherichia coli expressing curli or by Salmonella enteritidis expressing thin aggregative fimbriae, can be activated by simultaneously captured tissue-type plasminogen activator (t-PA). Mol Microbiol, 14, 443-52.

Skibsted, S, Jones, AE, Puskarich, MA, Arnold, R, Sherwin, R, Trzeciak, S, Schuetz, P, Aird, WC \& Shapiro, NI. (2013). Biomarkers of endothelial cell activation in early sepsis. Shock, 39, 427-32.

Smeesters, PR, McMillan, DJ \& Sriprakash, KS. (2010). The streptococcal M protein: a highly versatile molecule. Trends Microbiol, 18, 275-82.

Sodeinde, OA, Subrahmanyam, YV, Stark, K, Quan, T, Bao, Y \& Goguen, JD. (1992). A surface protease and the invasive character of plague. Science, 258, 1004-7.

Stie, J, Bruni, G \& Fox, D. (2009). Surface-associated plasminogen binding of Cryptococcus neoformans promotes extracellular matrix invasion. PLoS One, 4, e5780.

Sumby, P \& Waldor, MK. (2003). Transcription of the toxin genes present within the Staphylococcal phage phiSa3ms is intimately linked with the phage's life cycle. J Bacteriol, 185, 6841-51.

Sun, H, Ringdahl, U, Homeister, JW, Fay, WP, Engleberg, NC, Yang, AY, Rozek, LS, Wang, X, Sjobring, U \& Ginsburg, D. (2004). Plasminogen is a critical host pathogenicity factor for group A streptococcal infection. Science, 305, 1283-6.

Sun, H, Wang, X, Degen, JL \& Ginsburg, D. (2009). Reduced thrombin generation increases host susceptibility to group A streptococcal infection. Blood, 113, 1358-64.

Sun, H, Xu, Y, Sitkiewicz, I, Ma, Y, Wang, X, Yestrepsky, BD, Huang, Y, Lapadatescu, MC, Larsen, MJ, Larsen, SD, Musser, JM \& Ginsburg, D. (2012). Inhibitor of streptokinase gene expression improves survival after group A streptococcus infection in mice. Proc Natl Acad Sci U S A, 109, 3469-74.

Svensson, MD, Sjobring, U, Luo, F \& Bessen, DE. (2002). Roles of the plasminogen activator streptokinase and the plasminogen-associated $M$ protein in an experimental model for streptococcal impetigo. Microbiology, 148, 3933-45.

Ullberg, M, Kronvall, G, Karlsson, I \& Wiman, B. (1990). Receptors for human plasminogen on gram-negative bacteria. Infect Immun, 58, 21-5.

Ullberg, M, Kuusela, P, Kristiansen, BE \& Kronvall, G. (1992). Binding of plasminogen to Neisseria meningitidis and Neisseria gonorrhoeae and formation of surface-associated plasmin. J Infect Dis, 166, 1329-34.

Valls Seron, M, Haiko, J, De Groot, PG, Korhonen, TK \& Meijers, JC. (2010). Thrombin-activatable fibrinolysis inhibitor is degraded by Salmonella enterica and Yersinia pestis. J Thromb Haemost, 8, 2232-40.

van Lier, CJ, Sha, J, Kirtley, ML, Cao, A, Tiner, BL, Erova, TE, Cong, Y, Kozlova, EV, Popov, VL, Baze, WB \& Chopra AK. (2014). Deletion of Braun lipoprotein and plasminogen-activating protease-encoding genes attenuates Yersinia pestis in mouse models of bubonic and pneumonic plague. Infect Immun, 82, 2485-503.

Van Wamel, WJ, Rooijakkers, SH, Ruyken, M, Van Kessel, KP \& Van Strijp, JA. (2006). The innate immune modulators staphylococcal complement inhibitor and chemotaxis inhibitory protein of Staphylococcus aureus are located on beta-hemolysin-converting bacteriophages. J Bacteriol, 188, 1310-5.

Vanassche, T, Peetermans, M, Van Aelst, LN, Peetermans, WE, Verhaegen, J, Missiakas, DM, Schneewind, O, Hoylaerts, MF \& Verhamme, P. (2013). The role of staphylothrombin-mediated fibrin deposition in catheter-related Staphylococcus aureus infections. J Infect Dis, 208, 92-100.

Vanassche, T, Verhaegen, J, Peetermans, WE, Van Ryn, J, Cheng, A, Schneewind, O, Hoylaerts, MF \& Verhamme, P. (2011). Inhibition of staphylothrombin by dabigatran reduces Staphylococcus aureus virulence. J Thromb Haemost, 9, 2436-46.

Vassalli, JD, Baccino, D \& Belin, D. (1985). A cellular binding site for the $\mathrm{Mr} 55,000$ form of the human plasminogen activator, urokinase. J Cell Biol, 100, 86-92.

Verhamme, P \& Hoylaerts, MF. (2009). Hemostasis and inflammation: two of a kind? Thromb J, 7, 15.

Vieira, ML, Alvarez-Flores, MP, Kirchgatter, K, Romero, EC, Alves, IJ, De Morais, ZM, Vasconcellos, SA, Chudzinski-Tavassi, AM \& Nascimento, AL. (2013). Interaction of Leptospira interrogans with human proteolytic systems enhances dissemination through endothelial cells and protease levels. Infect Immun, 81, 1764-74.

Vieira, ML, Atzingen, MV, Oliveira, R, Mendes, RS, Domingos, RF, Vasconcellos, SA \& Nascimento, AL. (2012). Plasminogen binding proteins and plasmin generation on the surface of Leptospira spp.: the contribution to the bacteria-host interactions. J Biomed Biotechnol, 2012, 758513. 
Vieira, ML, De Morais, ZM, Vasconcellos, SA, Romero, EC \& Nascimento, AL. (2011). In vitro evidence for immune evasion activity by human plasmin associated to pathogenic Leptospira interrogans. Microb Pathog, 51, 360-5.

Vieira, ML, Vasconcellos, SA, Goncales, AP, De Morais, ZM \& Nascimento, AL. (2009). Plasminogen acquisition and activation at the surface of leptospira species lead to fibronectin degradation. Infect Immun, 77, 4092-101.

Virkola, R, Lahteenmaki, K, Eberhard, T, Kuusela, P, Van Alphen, L, Ullberg, M \& Korhonen, TK. (1996). Interaction of Haemophilus influenzae with the mammalian extracellular matrix. J Infect Dis, 173, 1137-47.

Wagemakers, A, Mason, LM, Oei, A, de Wever, B, van der Poll, T, Bins, AD \& Hovius, JW. (2014). Rapid outersurface protein C DNA tattoo vaccination protects against Borrelia afzelii infection. Gene Ther, 21, 1051-7.

Wang, X, Lin, X, Loy, JA, Tang, J \& Zhang, XC. (1998). Crystal structure of the catalytic domain of human plasmin complexed with streptokinase. Science, 281, 1662-5.

Wang, Z, Zhao, Q, Han, Y, Zhang, D, Zhang, L \& Luo, D. (2013). PAI-1 and IFN-gamma in the regulation of innate immune homeostasis during sublethal yersiniosis. Blood Cells Mol Dis, 50, 196-201.

Ward, PN, Field, TR, Rosey, EL, Abu-Median, AB, Lincoln, RA \& Leigh, JA. (2004). Complex interactions between bovine plasminogen and streptococcal plasminogen activator PauA. J Mol Biol, 342, 1101-14.

Westendorp, RG, Hottenga, JJ \& Slagboom, PE. (1999). Variation in plasminogen-activator-inhibitor-1 gene and risk of meningococcal septic shock. Lancet, 354, 561-3.

Whiting, GC, Evans, JT, Patel, S \& Gillespie, SH. (2002). Purification of native alpha-enolase from Streptococcus pneumoniae that binds plasminogen and is immunogenic. J Med Microbiol, 51, 837-43.

Wieckowska-Szakiel, M, Sadowska, B \& Rozalska, B. (2007). Staphylokinase production by clinical Staphylococcus aureus strains. Pol J Microbiol, 56, 97-102.

Wiggins, KJ, Johnson, DW, Craig, JC \& Strippoli, GF. (2007). Treatment of peritoneal dialysis-associated peritonitis: a systematic review of randomized controlled trials. Am J Kidney Dis, 50, 967-88.

Winram, SB \& Lottenberg, R. (1996). The plasmin-binding protein PIr of group A streptococci is identified as glyceraldehyde-3-phosphate dehydrogenase. Microbiology, 142 ( Pt 8), 2311-20.

Yavlovich, A, Katzenell, A, Tarshis, M, Higazi, AA \& Rottem, S. (2004). Mycoplasma fermentans binds to and invades HeLa cells: involvement of plasminogen and urokinase. Infect Immun, 72, 5004-11.

Yavlovich, A, Rechnitzer, H \& Rottem, S. (2007). Alpha-enolase resides on the cell surface of Mycoplasma fermentans and binds plasminogen. Infect Immun, 75, 5716-9.

Yun, TH, Cott, JE, Tapping, RI, Slauch, JM \& Morrissey, JH. (2009). Proteolytic inactivation of tissue factor pathway inhibitor by bacterial omptins. Blood, 113, 1139-48.

Zhan, L, Han, Y, Yang, L, Geng, J, Li, Y, Gao, H, Guo, Z, Fan, W, Li, G, Zhang, L, Qin, C, Zhou, D \& Yang, R. (2008). The cyclic AMP receptor protein, CRP, is required for both virulence and expression of the minimal CRP regulon in Yersinia pestis biovar microtus. Infect Immun, 76,5028-37.

Zhang, Y, Gladysheva, IP, Houng, AK \& Reed, GL. (2012a). Streptococcus uberis plasminogen activator (SUPA) activates human plasminogen through novel species-specific and fibrin-targeted mechanisms. J Biol Chem, 287, 19171-6.

Zhang, Y, Liang, Z, Hsueh, HT, Ploplis, VA \& Castellino, FJ. (2012b). Characterization of streptokinases from group A Streptococci reveals a strong functional relationship that supports the coinheritance of plasminogen-binding M protein and cluster 2b streptokinase. J Biol Chem, 287, 42093-103. 
Table 1. In vitro evidence for the role of plasminogen activation in bacterial virulence. $\mathrm{Plg}=$ plasminogen; $\mathrm{PA}=$ plasminogen activator.

\begin{tabular}{|c|c|c|}
\hline Pathogen & $\begin{array}{l}\text { ECM degradation and cellular } \\
\text { permeation (actor) }\end{array}$ & $\begin{array}{l}\text { Immune evasion } \\
\text { (actor) }\end{array}$ \\
\hline Yersinia pestis & $\begin{array}{l}\text { Degradation of laminin, heparan } \\
\text { sulphate proteoglycans and lung ECM } \\
\text { (Pla expressed in E. coli + human Plg) } \\
\text { (Lahteenmaki et al., 1998) }\end{array}$ & \\
\hline \multirow[t]{2}{*}{$\begin{array}{l}\text { Staphylococcus } \\
\text { aureus }\end{array}$} & $\begin{array}{l}\text { Penetration of Matrigel, keratinocyte } \\
\text { layer and skin biopsy specimen } \\
\text { (staphylokinase + human Plg) } \\
\text { (Kwiecinski et al., 2013) }\end{array}$ & $\begin{array}{l}\text { Removal of opsonizing IgG and C3b } \\
\text { from bacterial surface; protection } \\
\text { from Fc-receptor mediated } \\
\text { neutrophil phagocytosis } \\
\text { (staphylokinase + human Plg) } \\
\text { (Rooijakkers et al., 2005) }\end{array}$ \\
\hline & $\begin{array}{l}\text { Degradation of synthetic collagenase } \\
\text { substrate, via pro-MMP-1 activation } \\
\text { (surface bound human PIg + PA) } \\
\text { (Santala et al., 1999) }\end{array}$ & $\begin{array}{l}\mathrm{C} 3 / \mathrm{C} 3 \mathrm{~b} \text { degradation; protection } \\
\text { from complement mediated killing } \\
\text { (surface bound Plg, to Sbi and Efb } \\
\text { surface proteins, + staphylokinase } \\
\text { or host PA) } \\
\text { (Koch et al., 2012) }\end{array}$ \\
\hline \multirow[t]{2}{*}{$\begin{array}{l}\text { Group A } \\
\text { streptococci }\end{array}$} & $\begin{array}{l}\text { Pericellular penetration of pharyngeal } \\
\text { cells } \\
\text { (surface bound Plg + PA) } \\
\qquad \text { (Pancholi et al., 2003) }\end{array}$ & $\begin{array}{l}\text { C3b degradation; protection from } \\
\text { complement mediated killing by } \\
\text { polymorphonuclear leucocytes } \\
\text { (surface bound human Plg +/- SK) } \\
\text { (Ly et al., 2014) }\end{array}$ \\
\hline & & $\begin{array}{l}\text { Protection from macrophage killing } \\
\text { (surface bound human Plg/ } \\
\text { plasmin) } \\
\\
\text { (Siemens et al., 2011) }\end{array}$ \\
\hline \multirow[t]{2}{*}{$\begin{array}{l}\text { Group B } \\
\text { streptococci }\end{array}$} & 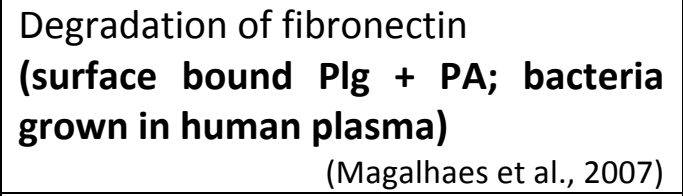 & \\
\hline & $\begin{array}{l}\text { Adhesion to and invasion of human } \\
\text { brain microvascular endothelial cells } \\
\text { (surface bound human Plg + PA; } \\
\text { bacteria grown in plasma) } \\
\text { (Magalhaes et al., 2013) }\end{array}$ & \\
\hline $\begin{array}{l}\text { Group C } \\
\text { streptococci } \\
\text { (S.dysgalactiae } \\
\text { ssp.equisimilis) } \\
\text { URL: http://mc. }\end{array}$ & $\begin{array}{l}\text { Degradation of fibronectin } \\
\text { (surface bound human PIg + PA) } \\
\text { (Bergmann et al., 2011) } \\
\text { manuscriptcentral.com/bmcb Email: mal }\end{array}$ & colm.richardson@manchester.ac.uk \\
\hline
\end{tabular}




\begin{tabular}{|c|c|c|}
\hline $\begin{array}{l}\text { Streptococcus } \\
\text { pneumoniae }\end{array}$ & $\begin{array}{l}\text { Degradation of Matrigel } \\
\text { (surface bound Plg + PA) } \\
\qquad \text { (Eberhard et al., 1999) }\end{array}$ & $\begin{array}{l}\text { C3/C3b cleavage } \\
\text { (surface protein Tuf or PepO + } \\
\text { human Plg }+ \text { PA) } \\
\text { (Mohan et al., 2014, Agarwal et al., 2013) }\end{array}$ \\
\hline & $\begin{array}{l}\text { Migration through lung epithelial cell } \\
\text { or endothelial cell layer by disruption } \\
\text { of intercellular junctions and VE- } \\
\text { cadherin degradation } \\
\text { (surface bound human Plg + PA) } \\
\text { (Attali et al., 2008a) }\end{array}$ & \\
\hline & $\begin{array}{l}\text { Deletion of plasminogen binding } \\
\text { motif in } \alpha \text {-enolase reduces } \\
\text { degradation of laminin, lung ECM and } \\
\text { Matrigel } \\
\text { (surface bound human Plg + PA) } \\
\text { (Bergmann et al., 2005) }\end{array}$ & \\
\hline & $\begin{array}{l}\text { Degradation of fibronectin and } \\
\text { laminin } \\
\text { (surface protein PepO + human Plg + } \\
\begin{array}{l}\text { PA) } \\
\text { (Agarwal et al., 2013) }\end{array}\end{array}$ & \\
\hline & $\begin{array}{l}\text { Deletion of plasminogen binding } \\
\text { protein CBPE reduces crossing of } \\
\text { Matrigel } \\
\text { (surface bound human Plg + PA) } \\
\text { (Attali et al., 2008b) }\end{array}$ & \\
\hline $\begin{array}{l}\text { Streptococcus } \\
\text { mutans }\end{array}$ & $\begin{array}{l}\text { Degradation of fibronectin } \\
\text { (surface bound human Plg +/- PA; or } \\
\text { bacteria grown in plasma or serum) } \\
\text { (Jones and Holt, 2004) }\end{array}$ & \\
\hline \multirow[t]{3}{*}{$\begin{array}{l}\text { Borrelia } \\
\text { burgdorferi }\end{array}$} & $\begin{array}{l}\text { Degradation of fibronectin, laminin, } \\
\text { vitronectin and ECM } \\
\text { (surface bound human Plg + PA) } \\
\text { (Coleman et al., 1999, } \\
\text { Coleman and Benach, 2000) }\end{array}$ & $\begin{array}{l}\text { Degradation of } \mathrm{C} 3 \mathrm{~b} \text { and } \mathrm{C} 5 \text { and } \\
\text { reduction of complement- } \\
\text { mediated bacteriolysis } \\
\text { (surface protein BBA70 + Plg + PA) } \\
\text { (Koenigs et al., 2013) }\end{array}$ \\
\hline & $\begin{array}{l}\text { Permeation of endothelial cell } \\
\text { monolayer } \\
\text { (surface bound human Plg + PA) } \\
\text { (Coleman et al., 1995) }\end{array}$ & \\
\hline & $\begin{array}{l}\text { Permeation of brain microvascular } \\
\text { endothelial cells } \\
\text { (surface bound human Plg + PA } \\
\text { produced by endothelial cells) } \\
\text { (Grab et al., 2005) }\end{array}$ & \\
\hline
\end{tabular}




\begin{tabular}{|c|c|c|}
\hline $\begin{array}{l}\text { Borrelia afzelii, } \\
\text { Borrelia } \\
\text { spielmanii }\end{array}$ & & $\begin{array}{l}\text { Degradation of C3b } \\
\text { (surface protein CspA + Plg + PA) } \\
\qquad \text { (Hammerschmidt et al., 2014) }\end{array}$ \\
\hline $\begin{array}{l}\text { Borrelia } \\
\text { recurrentis }\end{array}$ & & $\begin{array}{l}\text { Decrease in C3b deposition and } \\
\text { protection from complement- } \\
\text { mediated bacteriolysis } \\
\text { (surface protein hcpA + Plg + PA) } \\
\text { (Grosskinsky et al., 2009) }\end{array}$ \\
\hline \multirow[t]{2}{*}{$\begin{array}{l}\text { Leptospira } \\
\text { interrogans }\end{array}$} & $\begin{array}{l}\text { Degradation of fibronectin } \\
\text { (surface-bound human Plg + PA) } \\
\text { (Vieira et al., 2009) }\end{array}$ & $\begin{array}{l}\text { Removal of opsonizing C3b and } \\
\text { IgG, C3b degradation, protection } \\
\text { from complement mediated killing } \\
\text { (surface bound Plg + PA) } \\
\text { (Vieira et al., 2011) }\end{array}$ \\
\hline & $\begin{array}{l}\text { Permeation of endothelial cells } \\
\text { (surface bound human Plg +/- PA) } \\
\qquad \text { (Vieira et al., 2013) }\end{array}$ & \\
\hline $\begin{array}{l}\text { Bacillus } \\
\text { anthracis }\end{array}$ & $\begin{array}{l}\text { Degradation of fibronectin } \\
\text { (surface bound human Plg +/- PA) } \\
\qquad \text { (Agarwal et al., 2008) }\end{array}$ & $\begin{array}{l}\text { Cleavage and degradation of C3b } \\
\text { (surface bound human PIg + PA) } \\
\text { (Chung et al., 2011) }\end{array}$ \\
\hline $\begin{array}{l}\text { Haemophilus } \\
\text { influenza }\end{array}$ & $\begin{array}{l}\text { Degradation of fibronectin, laminin, } \\
\text { endothelial cell ECM and migration } \\
\text { through Matrigel } \\
\text { (surface bound human Plg + PA) } \\
\qquad \text { (Virkola et al., 1996) }\end{array}$ & $\begin{array}{l}\text { Degradation of C3b } \\
\text { (surface protein PE + human Plg + } \\
\text { PA) } \\
\qquad \text { (Barthel et al., 2012) }\end{array}$ \\
\hline $\begin{array}{l}\text { Salmonella } \\
\text { enterica var. } \\
\text { typhimurium }\end{array}$ & $\begin{array}{l}\text { Degradation of laminin, endothelial } \\
\text { cell basement membrane and } \\
\text { penetration through Matrigel } \\
\text { (surface bound human Plg + PA) } \\
\text { (Lahteenmaki et al., 1995) }\end{array}$ & $\begin{array}{l}\text { Increased C3b cleavage } \\
\text { (surface protein PgtE }+ \text { /- human } \\
\text { Plg / plasmin) } \\
\text { (Ramu et al., 2007) }\end{array}$ \\
\hline $\begin{array}{l}\text { Francisella } \\
\text { tularensis }\end{array}$ & $\begin{array}{l}\text { Degradation of fibronectin } \\
\text { (surface-bound human Plg + PA) }\end{array}$ & $\begin{array}{l}\text { Removal and degradation of } \\
\text { opsonizing IgG, leading to } \\
\text { decreased uptake by macrophages } \\
\text { and less TNF- } \alpha \text { and IL- } 6 \text { production } \\
\text { (surface bound Plg + PA; or } \\
\text { plasmin) } \\
\text { (Crane et al., 2009) }\end{array}$ \\
\hline $\begin{array}{l}\text { Mycoplasma } \\
\text { fermentans }\end{array}$ & $\begin{array}{l}\text { Invasion of HeLa cells } \\
\text { (surface bound PIg + PA) } \\
\qquad \text { (Yavlovich et al., 2004) }\end{array}$ & \\
\hline
\end{tabular}

URL: http://mc.manuscriptcentral.com/bmcb Email: malcolm.richardson@manchester.ac.uk 
Table 2. In vivo evidence for the role of plasminogen activation in bacterial virulence.

WT = wild type; SC = subcutaneous; IV = intravenous; Plg = plasminogen; Fib = fibrinogen; IN = intranasal; SAK = staphylokinase, huPlg = human plasminogen; $\mathrm{SK}$ = streptokinase; ID = intradermal; u-PA = urokinase; $\mathrm{PAM}=$ streptococcal $\mathrm{M}$ protein; IP = intraperitoneal; IT = intratracheal.

\begin{tabular}{|c|c|c|c|c|c|}
\hline Pathogen & Bacteria & Host (mice) & $\begin{array}{l}\text { Model / } \\
\text { parameter studied }\end{array}$ & Effect & Reference \\
\hline \multirow[t]{4}{*}{ Yersinia pestis } & WT vs. Pla- & 3 & $\begin{array}{l}\text { SC and IV / } \\
\text { mortality, metastatic } \\
\text { infection }\end{array}$ & $\begin{array}{l}\text { Pla- } Y \text {. pestis less virulent }\left(10^{6} \text {-fold increase }\right. \\
\left.L_{50}\right) \text { in SC, but not in IV model }\end{array}$ & $\begin{array}{l}\text { (Sodeinde e } \\
\text { al., 1992) }\end{array}$ \\
\hline & WT vs. Pla- & & $\begin{array}{l}\text { Flea-borne infection - } \\
\text { bubonic vs. systemic } \\
\text { plague / } \\
\text { mortality }\end{array}$ & $\begin{array}{l}\text { Pla- Y. Pestis can cause fatal systemic } \\
\text { plague but not bubonic plague }\end{array}$ & $\begin{array}{l}\text { (Sebbane et } \\
\text { al., 2006) }\end{array}$ \\
\hline & WT vs. Pla- & $\begin{array}{l}\text { WT vs. Plg -/- } \\
\text { vs. Fib -/- vs. } \\
\text { Fib -/-PIg -/- }\end{array}$ & $\begin{array}{l}\text { SC / } \\
\text { mortality }\end{array}$ & $\begin{array}{l}\text { Plg-/- mice are less susceptible to infection } \\
\left.\text { with } Y \text {. Pestis (100-fold increase } L_{50}\right) \\
\text { Fib -/- mice are more susceptible to } \\
\text { infection } \\
\text { Reduced virulence of } Y \text {. pestis in Plg-/- mice } \\
\text { is partially reversed by fibrin depletion }\end{array}$ & $\begin{array}{l}\text { (Goguen et } \\
\text { al., 2000, } \\
\text { Degen et al. } \\
\text { 2007) }\end{array}$ \\
\hline & WT vs. Pla- & & IN - pneumonic plague & $\begin{array}{l}\text { Pla- } Y \text {. Pestis show reduced proliferation in } \\
\text { lungs, reduced fibrin encapsulation and } \\
\text { inflammatory damage, and increased } \\
\text { survival }\end{array}$ & $\begin{array}{l}\text { (Lathem et } \\
\text { al., 2007) }\end{array}$ \\
\hline \multirow[t]{3}{*}{$\begin{array}{l}\text { Staphylococcus } \\
\text { aureus }\end{array}$} & $\begin{array}{l}\text { SAK- vs. SAK+ } \\
\text { vs. SAK } \\
\text { overproducing }\end{array}$ & WT vs. huPlg+ & $\begin{array}{l}\text { IV / } \\
\text { mortality }\end{array}$ & $\begin{array}{l}\text { SAK producing strains are less virulent, if } \\
\text { human Plg present }\end{array}$ & $\begin{array}{l}\text { (Kwiecinski } \\
\text { et al., 2010) }\end{array}$ \\
\hline & $\begin{array}{l}\text { SAK- vs. SAK+ } \\
\text { vs. SAK } \\
\text { overproducing }\end{array}$ & $\begin{array}{l}\text { WT vs. huPlg+ } \\
\text { neutropenic }\end{array}$ & $\begin{array}{l}\text { SC / } \\
\text { skin infection }\end{array}$ & $\begin{array}{l}\text { SAK overproducing strain causes smaller } \\
\text { and more open lesions }\end{array}$ & $\begin{array}{l}\text { (Kwiecinski } \\
\text { et al., 2013) }\end{array}$ \\
\hline & & $\begin{array}{l}\text { WT vs. huPlg } \\
\text { expression }\end{array}$ & $\begin{array}{l}\text { SC / } \\
\text { skin infection }\end{array}$ & $\begin{array}{l}\text { Presence of human Plg increases lesion size } \\
\text { and bacterial load }\end{array}$ & $\begin{array}{l}\text { (Peeterman } \\
\text { et al., 2014) }\end{array}$ \\
\hline
\end{tabular}




\begin{tabular}{|c|c|c|c|c|c|}
\hline $\begin{array}{l}\text { Group A } \\
\text { streptococci }\end{array}$ & SK+ vs. SK- & $\begin{array}{l}\text { WT vs. huPlg + } \\
\text { Fib depletion } \\
\text { (Ancrod) }\end{array}$ & $\begin{array}{l}\text { SC or IV / } \\
\text { mortality, metastatic } \\
\text { infection }\end{array}$ & $\begin{array}{l}\text { Presence of human Plg increases mortality } \\
\text { and systemic infection in SC, but not in IV } \\
\text { model. Increased mortality in Fib-depleted } \\
\text { mice. SK- mutant is less virulent in huPlg + } \\
\text { mice (difference not significant in WT mice) }\end{array}$ & $\begin{array}{l}\text { (Sun et al., } \\
2004 \text { ) }\end{array}$ \\
\hline & SK+ vs. SK- & $\begin{array}{l}\text { Treatment with } \\
\text { human Plg }\end{array}$ & $\begin{array}{l}\text { SC / } \\
\text { skin lesions and } \\
\text { mortality }\end{array}$ & $\begin{array}{l}\text { Presence of human Plg enhances virulence, } \\
\text { counteracted by plasmin inhibitor. Effect } \\
\text { more pronounced in SK+ vs. SK- GAS }\end{array}$ & $\begin{array}{l}\text { (Khil et al., } \\
\text { 2003) }\end{array}$ \\
\hline & $\begin{array}{l}\text { Preincubation } \\
\text { with human } \\
\text { plasma or } \\
\text { huPlg, Fib and } \\
\text { SK }\end{array}$ & WT vs. Plg - & $\begin{array}{l}\text { ID skin air sac / } \\
\text { skin lesions, mortality }\end{array}$ & $\begin{array}{l}\text { Preincubation with human Plg, Fib, SK or } \\
\text { human plasma }+ \text { SK increases virulence in } \\
\text { Plg+, but not in Plg- mice, pointing to the } \\
\text { role of surface bound plasmin and } \\
\text { secondary activation of murine Plg }\end{array}$ & $\begin{array}{l}\text { (Li et al., } \\
\text { 1999) }\end{array}$ \\
\hline & SK+ vs. SK- & $\begin{array}{l}\text { WT vs. huPlg + } \\
\text { vs. u-PA - }\end{array}$ & $\begin{array}{l}\text { ID / } \\
\text { mortality, metastatic } \\
\text { infection, bacteremia }\end{array}$ & $\begin{array}{l}\text { Presence of human PIg and u-PA increases } \\
\text { mortality and dissemination. Increased } \\
\text { virulence of SK+ strain in UPA-/- background }\end{array}$ & $\begin{array}{l}\text { (Sanderson- } \\
\text { Smith et al., } \\
\text { 2013) }\end{array}$ \\
\hline & $\begin{array}{l}\text { SK+ vs. SK- } \\
\text { PAM+ vs. PAM- }\end{array}$ & $\begin{array}{l}\text { human foreskin } \\
\text { graft in SCID } \\
\text { mice }\end{array}$ & $\begin{array}{l}\text { Infection of damaged } \\
\text { skin / } \\
\text { skin lesions }\end{array}$ & $\begin{array}{l}\text { Both PAM-deletion and SK-deletion reduce } \\
\text { pathological changes. Effect of SK-deletion } \\
\text { more pronounced }\end{array}$ & $\begin{array}{l}\text { (Svensson et } \\
\text { al., 2002) }\end{array}$ \\
\hline & WT vs. PAM - & WT vs. huPlg + & $\begin{array}{l}\text { SC / } \\
\text { mortality, metastatic } \\
\text { infection }\end{array}$ & $\begin{array}{l}\text { PAM- mutant is less virulent in huPlg }+ \text { mice } \\
\text { (difference not significant in WT mice) }\end{array}$ & $\begin{array}{l}\text { (Sun et al., } \\
2004 \text { ) }\end{array}$ \\
\hline & WT vs. prp - & huPlg + & $\begin{array}{l}\text { SC / } \\
\text { mortality }\end{array}$ & $\begin{array}{l}\text { Inactivation of Plg-binding protein prp } \\
\text { reduces virulence in huPlg + mice }\end{array}$ & $\begin{array}{l}\text { (Sanderson- } \\
\text { Smith et al., } \\
\text { 2008) }\end{array}$ \\
\hline & WT vs. prp- & huPlg + & $\begin{array}{l}\text { ID / } \\
\text { lesion bacterial load }\end{array}$ & $\begin{array}{l}\text { Increased bacterial survival, less C3b } \\
\text { deposition and neutrophil accumulation }\end{array}$ & $\begin{array}{l}\text { (Ly et al., } \\
2014)\end{array}$ \\
\hline & WT vs. speB- & huPlg + & $\begin{array}{l}\text { SC / } \\
\text { mortality, bacteremia }\end{array}$ & $\begin{array}{l}\text { SpeB loss results in increased plasmin } \\
\text { acquisition and increases mortality and } \\
\text { invasiveness in huPlg + mice }\end{array}$ & $\begin{array}{l}\text { (Cole et al., } \\
2006 \text { ) }\end{array}$ \\
\hline
\end{tabular}




\begin{tabular}{|c|c|c|c|c|c|}
\hline $\begin{array}{l}\text { Group B } \\
\text { streptococci } \\
\text { (S. agalactiae) }\end{array}$ & $\begin{array}{l}\text { incubation with } \\
\text { human Plg and } \\
\text { t-PA }\end{array}$ & & $\begin{array}{l}\text { IP / } \\
\text { liver count of bacteria }\end{array}$ & $\begin{array}{l}\text { Pre-incubation with human Plg and t-PA } \\
\text { enhances virulence and decreases clearance } \\
\text { from liver }\end{array}$ & $\begin{array}{l}\text { (Magalhaes } \\
\text { et al., 2007) }\end{array}$ \\
\hline & & $\begin{array}{l}\text { EACA } \\
\text { treatment of } \\
\text { mothers }\end{array}$ & $\begin{array}{l}\text { IP - neonatal mouse } \\
\text { meningitis / } \\
\text { organ bacterial load }\end{array}$ & $\begin{array}{l}\text { More penetration of blood brain barrier, } \\
\text { reduced by EACA treatment }\end{array}$ & $\begin{array}{l}\text { (Magalhaes } \\
\text { et al., 2013) }\end{array}$ \\
\hline $\begin{array}{l}\text { Streptococcus } \\
\text { pneumoniae }\end{array}$ & $\begin{array}{l}\text { WT vs. } \alpha \text { - } \\
\text { enolase mutant }\end{array}$ & 8 & $\begin{array}{l}\text { IN - pneumonia model / } \\
\text { mortality }\end{array}$ & $\begin{array}{l}\text { Mutation in Plg-binding motif of } \alpha \text {-enolase } \\
\text { reduces virulence }\end{array}$ & $\begin{array}{l}\text { (Bergmann } \\
\text { et al., 2003) }\end{array}$ \\
\hline \multirow[t]{3}{*}{$\begin{array}{l}\text { Borrelia } \\
\text { burgdorferi }\end{array}$} & & WT vs. Plg -/- & $\begin{array}{l}\text { Tick-borne infection - } \\
\text { SC / } \\
\text { dissemination in tick } \\
\text { and in mice }\end{array}$ & $\begin{array}{l}\text { Plg-deficiency decreases dissemination in } \\
\text { ticks, leads to longer attachment of nymphs } \\
\text { and reduces spirochetemia in mice }\end{array}$ & $\begin{array}{l}\text { (Coleman et } \\
\text { al., 1997) }\end{array}$ \\
\hline & $\begin{array}{l}\text { WT vs. OspC } \\
\text { mutant }\end{array}$ & & $\begin{array}{l}\text { Tick-borne infection / } \\
\text { organ bacterial load }\end{array}$ & $\begin{array}{l}\text { Low-affinity binding of Plg in OspC mutant } \\
\text { reduces invasiveness (heart, joint, ear skin) }\end{array}$ & $\begin{array}{l}\text { (Lagal et al., } \\
2006)\end{array}$ \\
\hline & & $\begin{array}{l}\text { Active } \\
\text { immunisation } \\
\text { to enolase }\end{array}$ & $\begin{array}{l}\text { SC and tick-borne } \\
\text { infection / } \\
\text { acquisition in tick }\end{array}$ & Lower acquisition of Borrelia in tick & $\begin{array}{l}\text { (Nogueira et } \\
\text { al., 2012) }\end{array}$ \\
\hline $\begin{array}{l}\text { Borrelia from } \\
\text { patient with } \\
\text { relapsing fever }\end{array}$ & & WT vs. Plg -/- & $\begin{array}{l}\text { SC / } \\
\text { penetration in brain } \\
\text { and heart }\end{array}$ & $\begin{array}{l}\text { Plg deficiency reduces invasion of brain and } \\
\text { heart }\end{array}$ & $\begin{array}{l}\text { (Gebbia et } \\
\text { al., 1999) }\end{array}$ \\
\hline $\begin{array}{l}\text { Borrelia } \\
\text { crocidurae }\end{array}$ & & WT vs. Plg -/- & $\begin{array}{l}\text { IP / } \\
\text { bacteremia } \\
\text { pathological changes }\end{array}$ & $\begin{array}{l}\text { Plg -/- mice have equal levels of circulating } \\
\text { bacteria but reduced invasion and } \\
\text { inflammation of brain and kidney }\end{array}$ & $\begin{array}{l}\text { (Nordstrand } \\
\text { et al., 2001) }\end{array}$ \\
\hline $\begin{array}{l}\text { Aeromonas } \\
\text { hydrophila }\end{array}$ & & $\begin{array}{l}\text { Immunization } \\
\text { to enolase }\end{array}$ & $\begin{array}{l}\text { IV / } \\
\text { mortality, bacterial } \\
\text { load }\end{array}$ & $\begin{array}{l}\text { Immunized mice are protected from lethal } \\
\text { challenge and have reduced bacterial loads } \\
\text { in liver and spleen }\end{array}$ & $\begin{array}{l}\text { (Sha et al., } \\
\text { 2009) }\end{array}$ \\
\hline $\begin{array}{l}\text { Mycobacterium } \\
\text { avium }\end{array}$ & & WT vs. Plg -/- & $\begin{array}{l}\text { IT / } \\
\text { organ bacterial load }\end{array}$ & $\begin{array}{l}\text { Absence of Plg leads to earlier } \\
\text { dissemination (higher liver and spleen CFU } \\
\text { counts after one week) and more fibrin } \\
\text { deposition and neutrophil infiltration }\end{array}$ & $\begin{array}{l}\text { (Sato et al., } \\
\text { 2003) }\end{array}$ \\
\hline
\end{tabular}




\section{Figure 1. Overview of the coagulation and fibrinolytic system with special reference to plasmin} substrates and fibrinolytic inhibitors.

PlgRs = plasminogen receptors; $t-P A=$ tissue type plasminogen activator; $u-P A=$ urokinase; u-PAR = u-PA receptor; PAI-1 = plasminogen activator inhibitor 1 ; $a 2 A P=$ alpha-2-antiplasmin; $a 2 \mathrm{M}=$ alpha-2macroglobulin; MMPs = matrix metalloproteinases; $\mathrm{ECM}=$ extracellular matrix. $258 \times 172 \mathrm{~mm}(300 \times 300 \mathrm{DPI})$ 


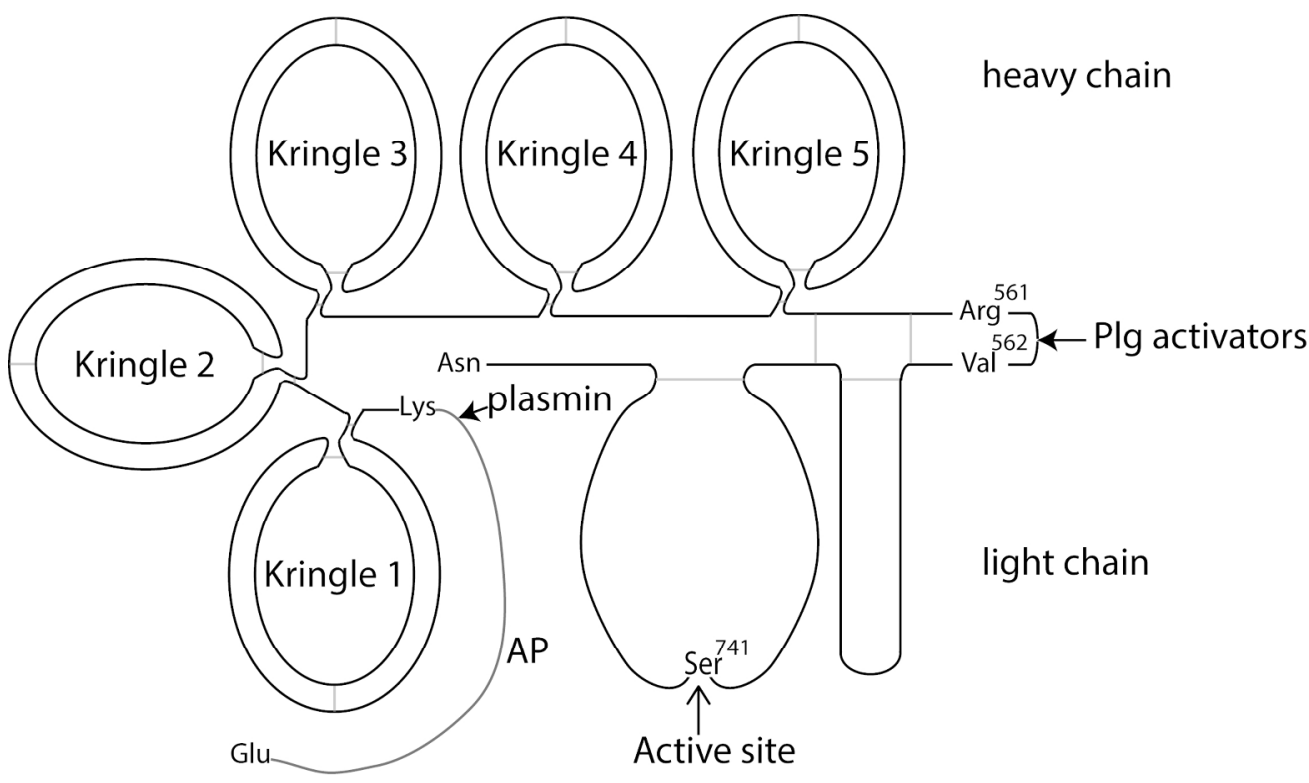

Figure 2. Domain structure of plasminogen.

Plasminogen $(\mathrm{Plg}$ ) contains five kringle domains and an active serine protease site. Disulfide bridges are marked in grey. Plg is activated by plasminogen activators (Plg activators) through cleavage between $\operatorname{Arg}^{561}$ and $\mathrm{Val}^{562}$, as indicated. This leads to formation of plasmin, consisting of a heavy chain and a light chain. Conversion of Glu-Plg to Lys-Plg involves removal of the C-terminal activation peptide (AP) by plasmin. $191 \times 129 \mathrm{~mm}(300 \times 300 \mathrm{DPI})$ 
A.

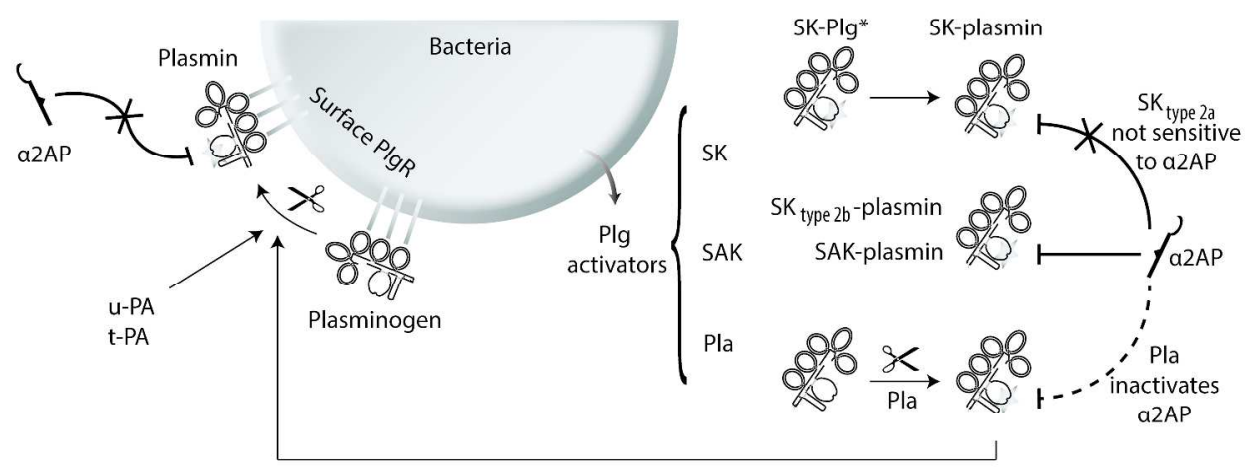

B.

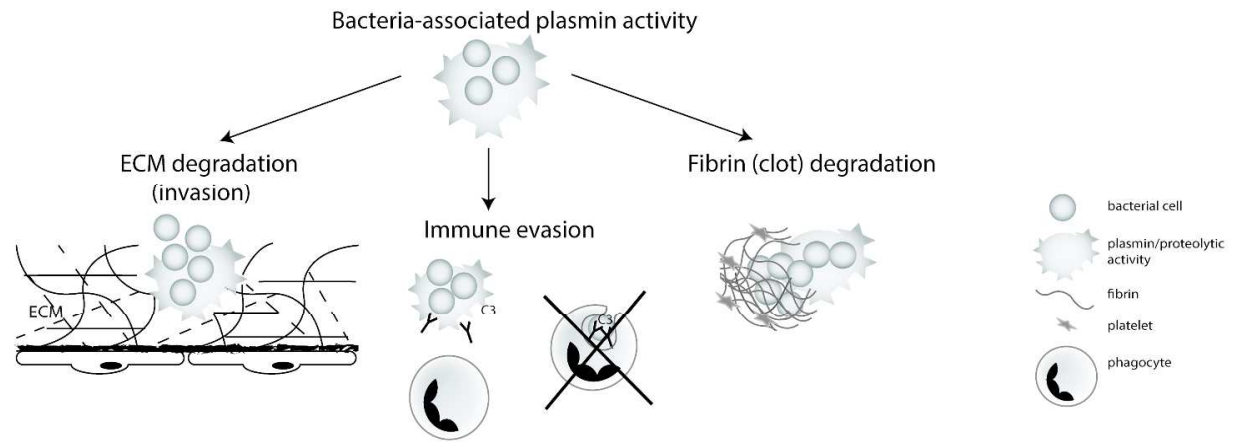

Figure 3. Mechanisms of plasminogen activation by bacteria and its role in bacterial virulence. A. Bacteria can bind plasminogen (Plg) to their surface, using specialized surface plasminogen receptors (PlgRs) that interact with the kringle domains of Plg. Surface-bound Plg can be easily activated by plasminogen activators (t-PA or u-PA); the resulting surface-associated plasmin activity is protected from alpha-2-antiplasmin (a2AP) inhibition. Alternatively, some bacteria produce a specific bacterial plasminogen activator (Plg activator), such as Pla protease (from Y. pestis) and the nonproteolytic Plg activators streptokinase (SK from group A, C and G streptococci) and staphylokinase (SAK from S. aureus).

B. The plasmin activity generated by bacteria is involved in bacterial invasion through degradation of extracellular matrix (ECM); in escape from the immune system (immune evasion), e.g. through removal of opsonizing complement factors and immunoglobulins; and in degradation of the fibrin that is formed around the bacterial colony. $297 \times 234 \mathrm{~mm}(300 \times 300$ DPI $)$ 


\section{Figure captions}

Figure 1. Overview of the coagulation and fibrinolytic system with special reference to plasmin substrates and fibrinolytic inhibitors.

$\mathrm{PlgRs}=$ plasminogen receptors; $\mathrm{t}-\mathrm{PA}=$ tissue type plasminogen activator; $\mathrm{u}-\mathrm{PA}=$ urokinase; $\mathrm{u}-\mathrm{PAR}=\mathrm{u}-\mathrm{PA}$ receptor; $\mathrm{PAI}-1=$ plasminogen activator inhibitor $1 ; \alpha 2 \mathrm{AP}=$ alpha-2antiplasmin; $\alpha 2 \mathrm{M}=$ alpha-2-macroglobulin; $\mathrm{MMPs}=$ matrix metalloproteinases; $\mathrm{ECM}=$ extracellular matrix.

\section{Figure 2. Domain structure of plasminogen.}

Plasminogen (Plg) contains five kringle domains and an active serine protease site. Disulfide bridges are marked in grey. Plg is activated by plasminogen activators (Plg activators) through cleavage between $\operatorname{Arg}^{561}$ and $\mathrm{Val}^{562}$, as indicated. This leads to formation of plasmin, consisting of a heavy chain and a light chain. Conversion of Glu-Plg to Lys-Plg involves removal of the C-terminal activation peptide (AP) by plasmin.

\section{Figure 3. Mechanisms of plasminogen activation by bacteria and its role in bacterial virulence.}

A. Bacteria can bind plasminogen (Plg) to their surface, using specialized surface plasminogen receptors (PlgRs) that interact with the kringle domains of Plg. Surface-bound Plg can be easily activated by plasminogen activators (t-PA or u-PA); the resulting surfaceassociated plasmin activity is protected from alpha-2-antiplasmin ( $\alpha 2 A P$ ) inhibition. Alternatively, some bacteria produce a specific bacterial plasminogen activator (Plg activator), such as Pla protease (from $Y$. pestis) and the nonproteolytic Plg activators 
streptokinase (SK from group A, C and G streptococci) and staphylokinase (SAK from S. aureus).

B. The plasmin activity generated by bacteria is involved in bacterial invasion through degradation of extracellular matrix (ECM); in escape from the immune system (immune evasion), e.g. through removal of opsonizing complement factors and immunoglobulins; and in degradation of the fibrin that is formed around the bacterial colony.

URL: http://mc.manuscriptcentral.com/bmcb Email: malcolm.richardson@manchester.ac.uk 